\title{
التناسب البياني في السنّة النّبويّة
}

\section{* محمد مختار المفتي}

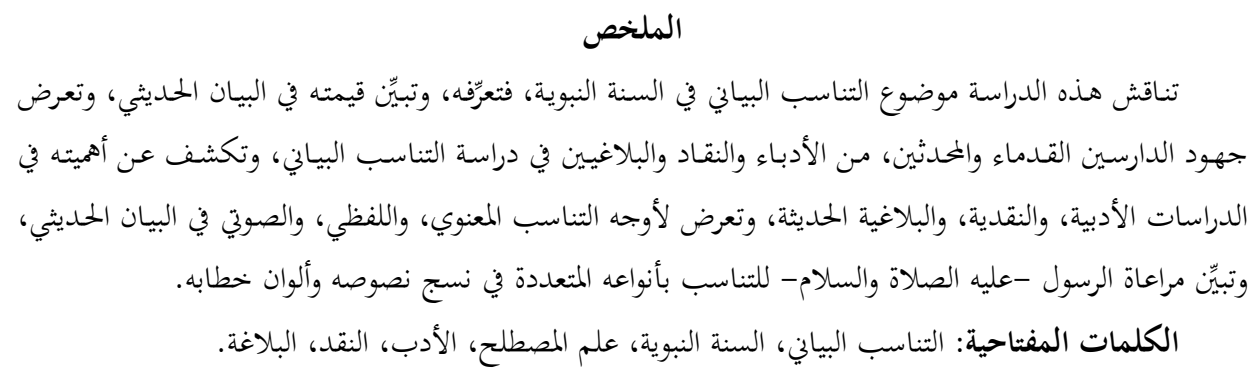

\section{The Rhetorical Proportionality in the Prophetic Tradition (Sunnah)}

\section{Abstract}

This study discusses the rhetorical proportionality in the Prophetic tradition (Sunnah), its definition and value. It presents efforts of ancient and contemporary researchers, writers, critics and rhetoricians in the study of rhetorical proportionality. The study reveals the importance of such efforts, and demonstrates aspects of moral, verbal, and phonetical proportionality in the Prophetic tradition, and shows that the Prophet (peace be upon him) has structured utterances of all his discourse forms using various types of proportionality.

Key words: Rhetorical proportionality, Prophetic tradition (Hadith), Terminology, literature, criticism, rhetoric.

$$
\begin{aligned}
& \text { "دكتوراه في الحديث الشريف وعلومه، عضو هيئة تدريس في قسم أصول الدين في كلية الشريعة، جامعة آل البيت، الريت } \\
& \text { الأردن. البريد الإلكتروني: mohammadmufty@yahoo.com }
\end{aligned}
$$

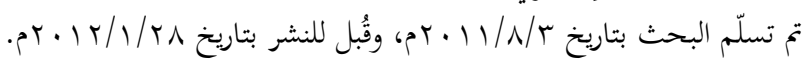


مقدمة:

تتناول هذه الدراسة التناسب البياني في السنة النبوية، وتبيّن أهميته، وجهود الدارسين القدامى والمحدثين من الأدباء في دراسته، كما تعرض لأوجه التناسب المعنوي، واللفظي، والصوتي في البيان الحميثي، والخصائص الفنية التي يتصف بها الحلديث النبوي من حيث قيمتـه، وتناسـب معانيسه، وألفاظـه، وأصـواته، وإيقاعاتـه، وتلقـي الضـوء على تناسـبـ

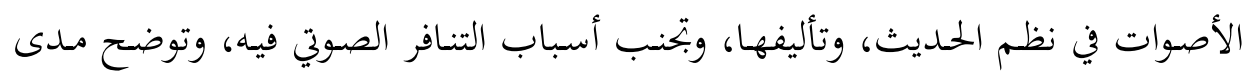
التناسـب بــن المعـنى والإيقـاع الصـوتي في الخطـاب الحـديثي، ومـــى ارتباطـه بــلالاتات

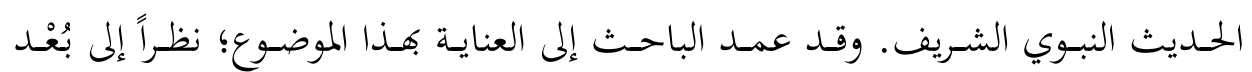

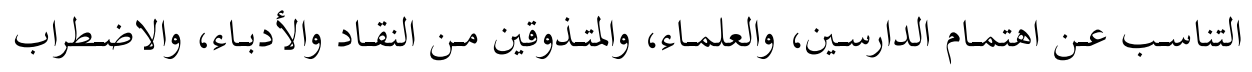

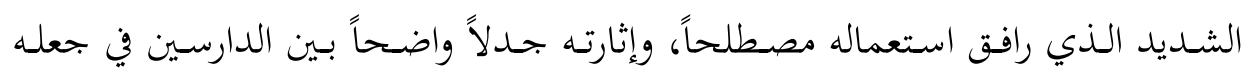

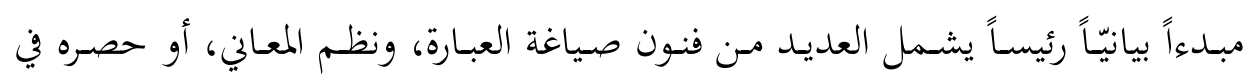

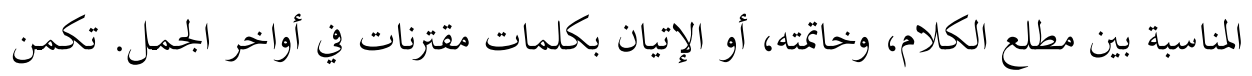

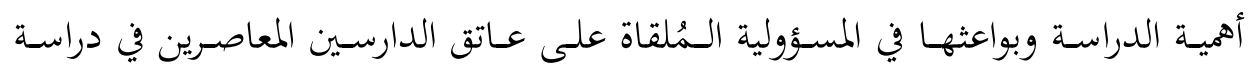
التناسب البياني وأهميته المرتبطة بالحقول الأدبية، والنقدية، والبلاغية، والعلوم الدينية كلها. وبما أن هذا المصطلح يُعَدّ أحد أهم عناصر الجمال، وأبرز شروط البلاغة والفصاحة

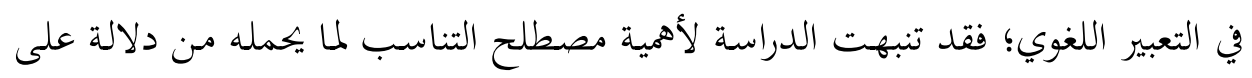
جودة النظم، وجمع العناصر التي يتألف منها الكالام، ودقة نسج المقاطع الصوتية المكونة

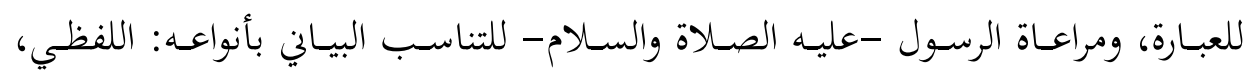
والمعنـوي، والصـوتي، والإيقـاعي في نسـج نصوصـه الثابتـة ضـمن سـياق تقـل فيـه دراسـة

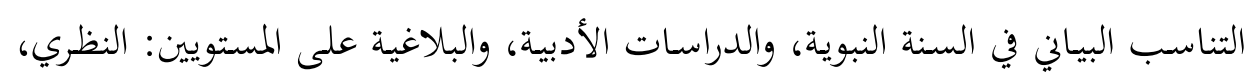
والتطبيقي. 


\section{أولاً: التناسب البياني والدراسات الأدبية القديمة}

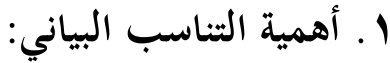

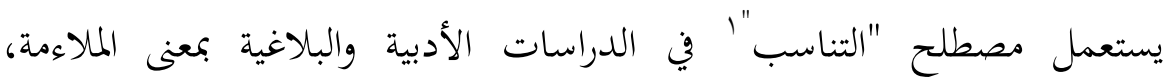

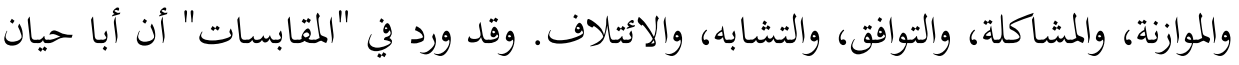

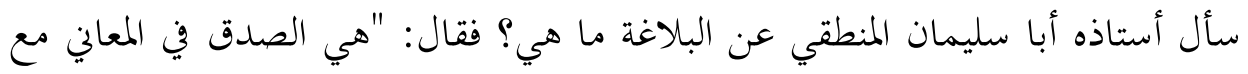

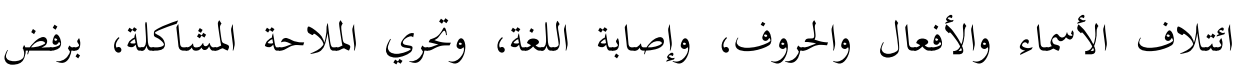

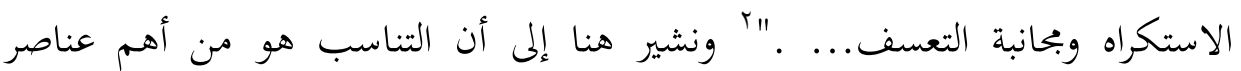

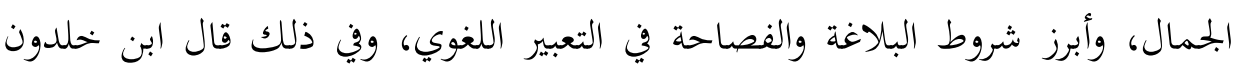

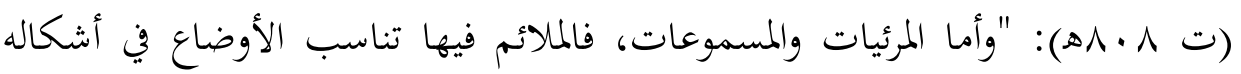

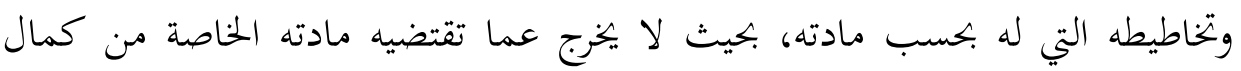

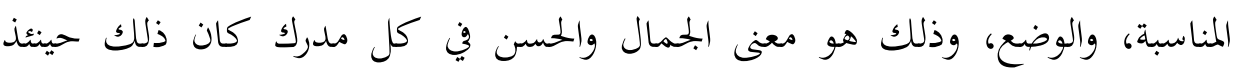

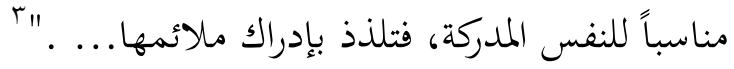

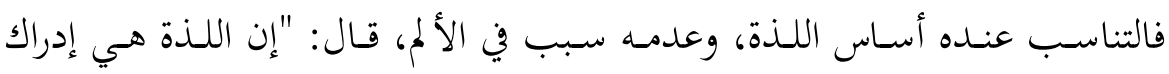

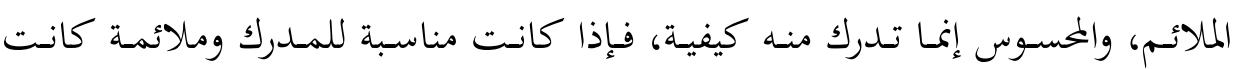

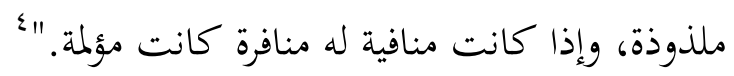

والحديث النبوي نص متناسب لا يعلو عليه في بحال البيان إلا كتاب الله بلاغة،

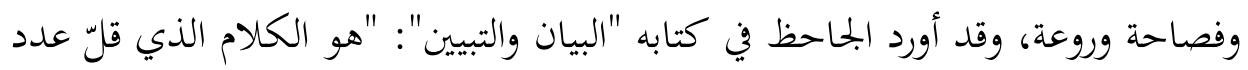

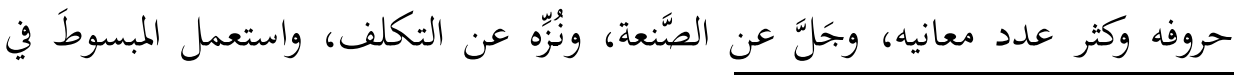

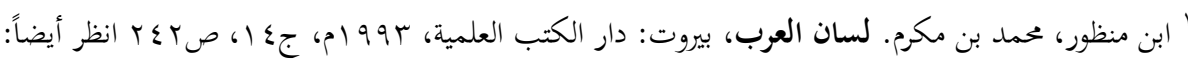

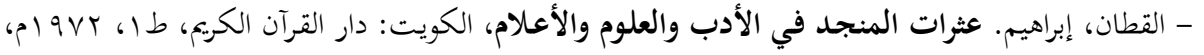

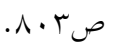

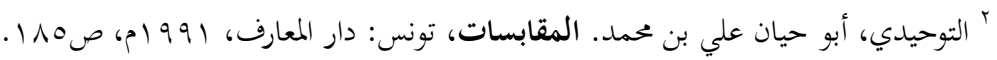

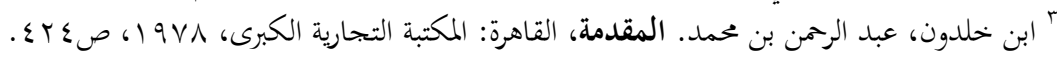

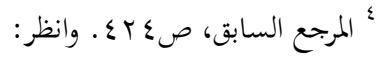
- البقالي، ناديا، "التناسب البياني في الحديث: دراسة في النظم المعنوي والصوتي"، أطروحة دكتوراه، جامعة حمد المبا

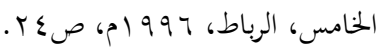


موضع البسط، والمقصورَ في موضع القصر، وهَجَر الغريبَ الوحشيَّ، ورغِبَ عن الهجين

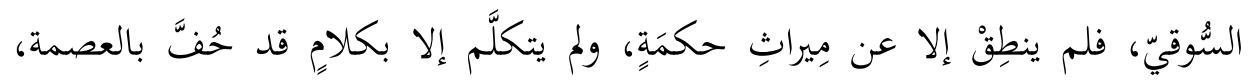

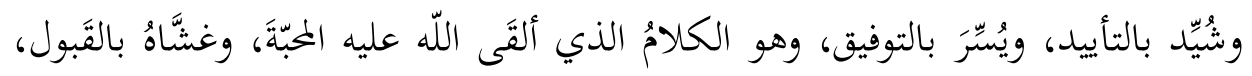

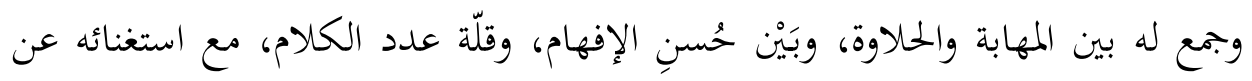

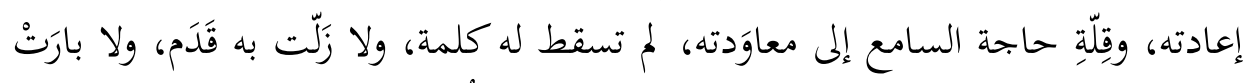

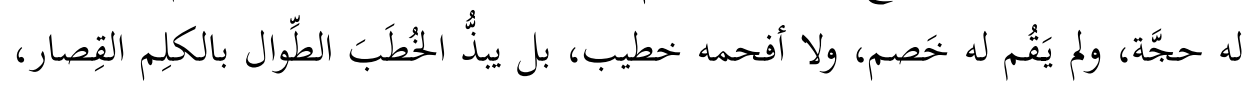

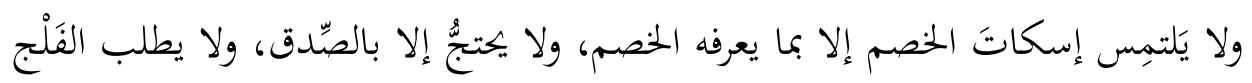

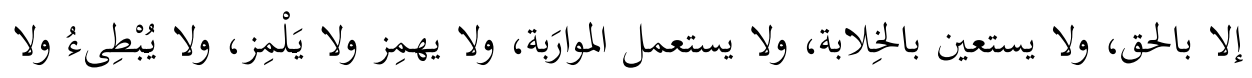

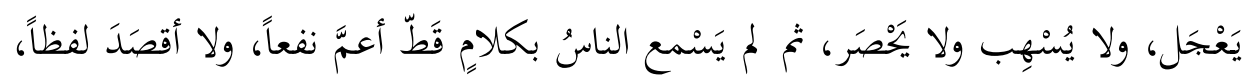

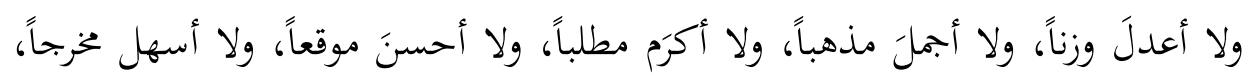

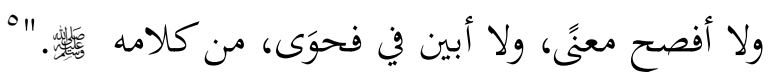

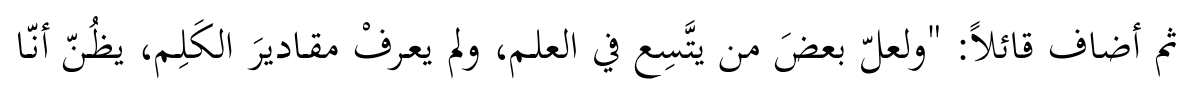

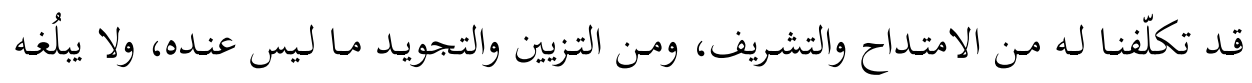

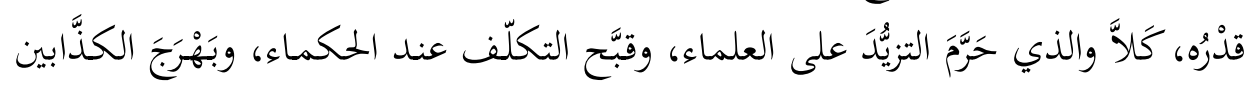

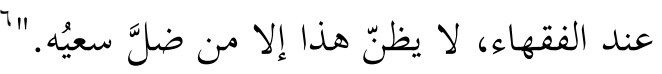

لم يكن التناسب مقصوراً على البنية العامة لنصوص الحمديث النبوي، والجحودة العالية لأسلوبه، وعمق معانيه، وانتقائه الكلمة المفردة والجملة المركبة، بل جاوز ذلك الك إلك إلى الأداء.

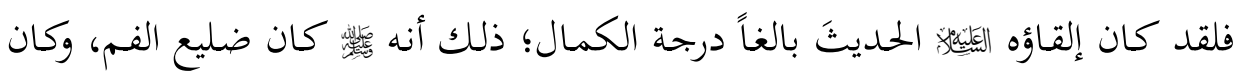
يستعمل فمه جميعه إذا تكلم، وعرف بطول سكوته، لا يتكلم في غير حاجة، وإذا تكلم

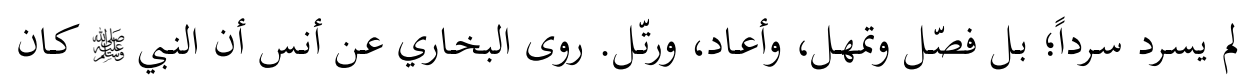

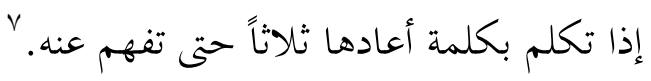

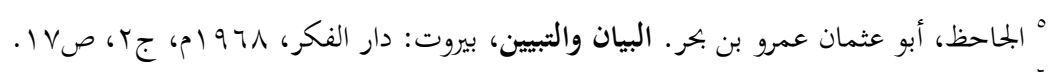

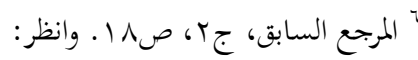

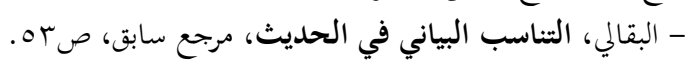

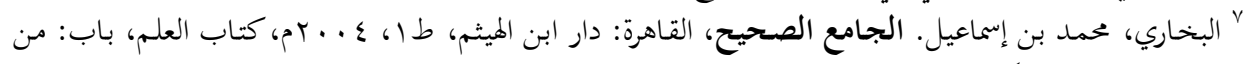

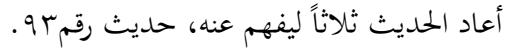


أمّا معاني الحديث ففيها غنى مدهش، مع عمق الأفكار وجِدّة المبادئ: "أيها الناس

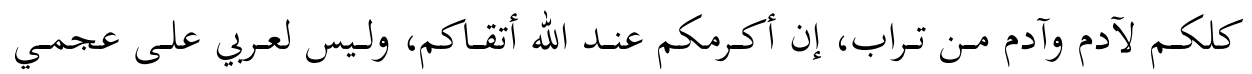

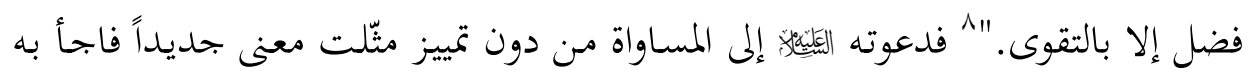

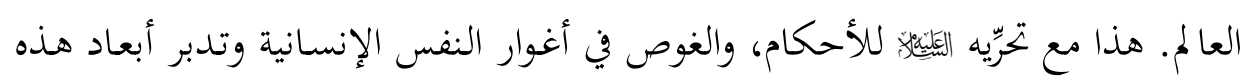

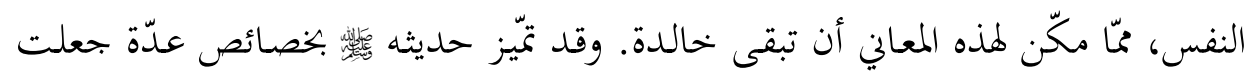

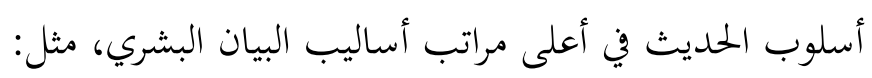
- - نظم المعاني الكثيرة بالمفردات القليلة مع حسن الصياغة، قال الرافعي: "إنه كلام كلما زدته فكراً زادك معنى." - - تـأثيره في سـامعيه واستحواذه على إعجـابهم؛ وذلك لانتقائـه الكلمـة المفــدة، والجملة المركبة، والألفاظ المتناسبة ذوات الإيقاع الموسيقي المحبب. - بُعده عن التكلف، وبحديده في أساليب النثر العربي.

\section{Y ب التناسب عند علماء البيان:}

أدرك البيانيون ما للتناسب المعنوي واللفظي من أثر في جودة الكالام، وزيادة حظه

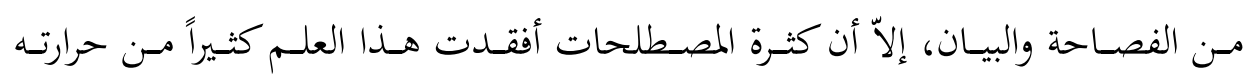
وروعته، فغابت بذلك بعض معالم أصالته، وتعمقه في الخصائص البيانية والصوتية التي

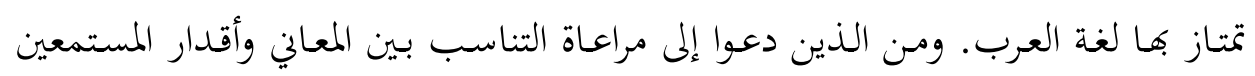
بشر بن المعتمر، فقال: "ينبغي للمتكلم أن يعرف أقدار المعاني، ويوازن بينها وبين أقدار

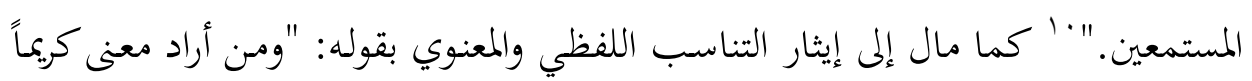

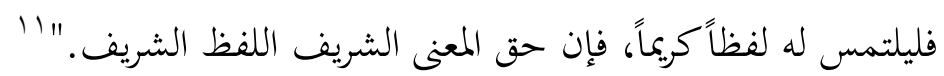
^ الطبراني، أبو القاسم سليمان بن أحمد الشامي. المعجم الكبير، الرياض: دار الصميعي، ط1، ـ99 19، حديث

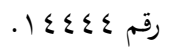

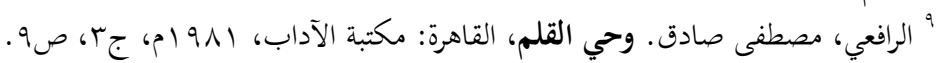

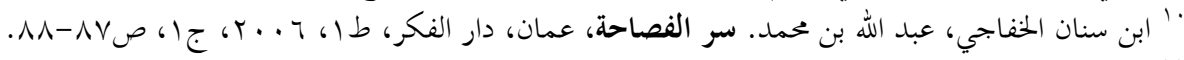

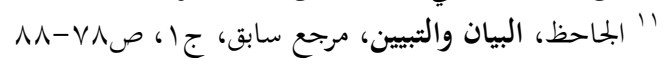




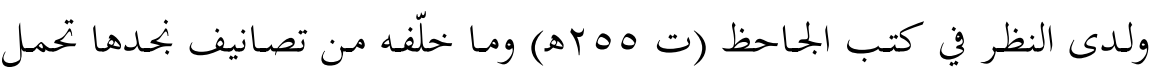

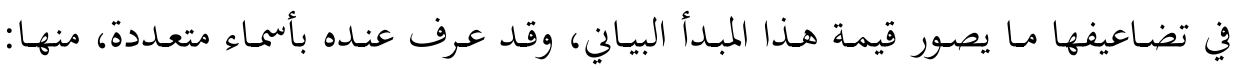

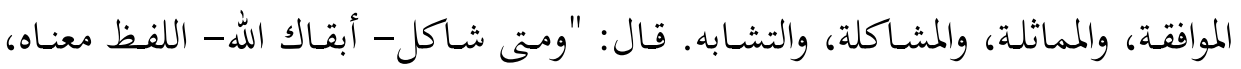

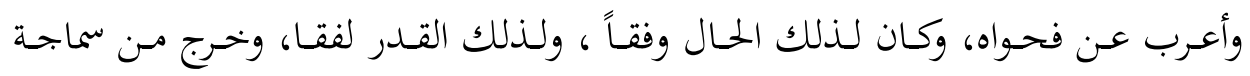

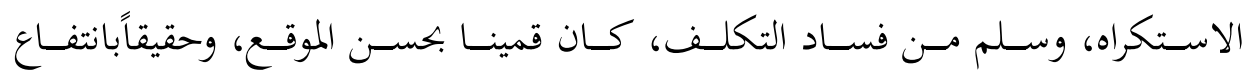
المستمع." الاستخرو

وقال: "إذا كـان الشعر مستكرهاً وكانـت ألفـاظ البيـت مـن الشعر لا يقع بعضهـا

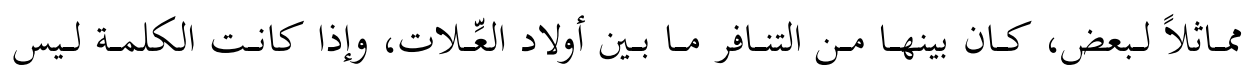

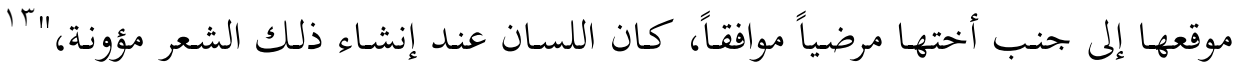

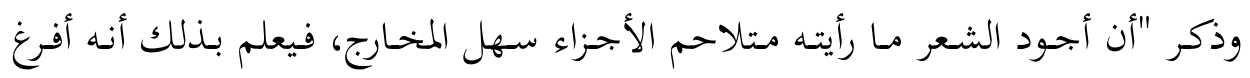

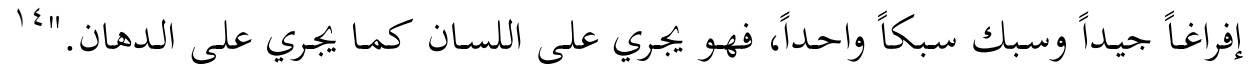

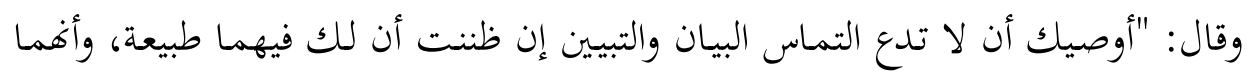
يناسبانك بعض المناسبة ويشاكلانك في بعض المشاكلة."

ولا نكاد نفرق بين مصطلح المناسبة، ومصطلح المشاكلة في وصيته تلك. كما أنه

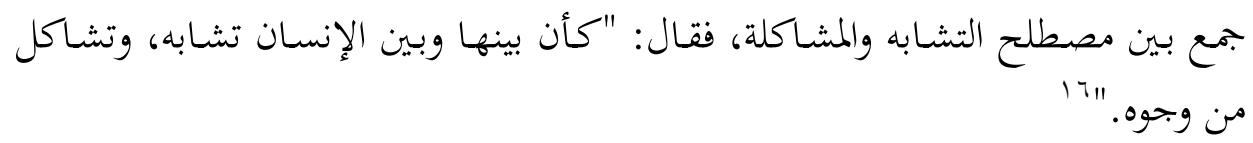

لقد تحدث الجاحظ عن قيمة التناسب في سلامة الشعر والنثر بمصطلحات متقاربة،

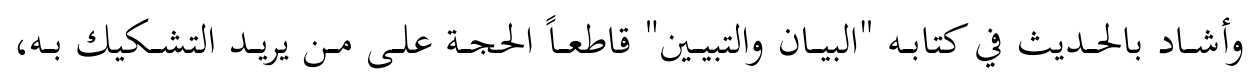

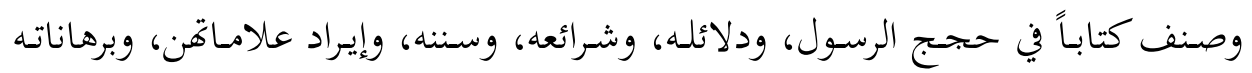

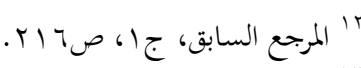

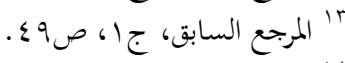

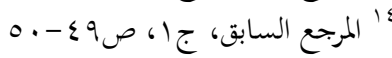

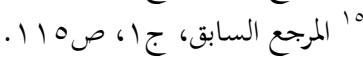

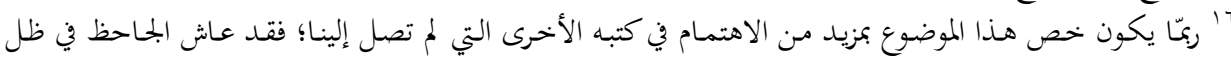

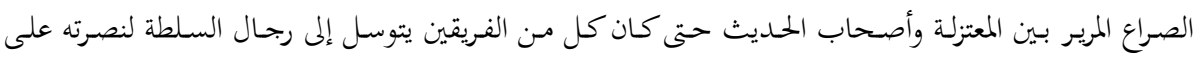

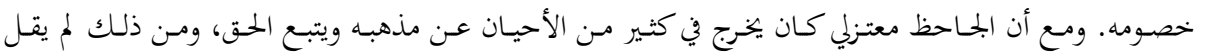
بالصِّرفة. 
ودلائله وآياته، وصنوف بدائعه وأنواع عجائبه في مقامه وظعنه، وعند دعائه واحتجاجه

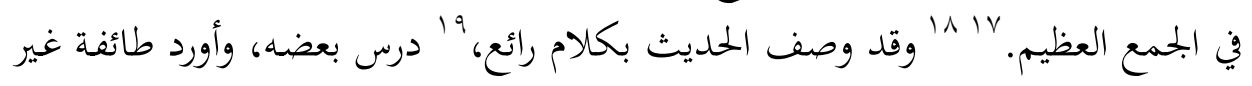
قليلة من دون تحليل أو تعليق، أو، دراسة.

أمّا الشريف الرضي (ت 7 · عهـ) فوظّف مصطلح "الموافقة" و "المواتاة" للتعبير عن

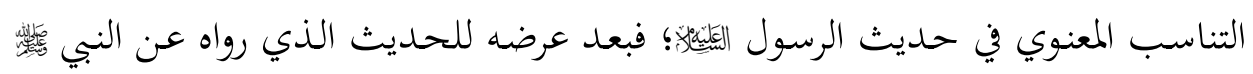

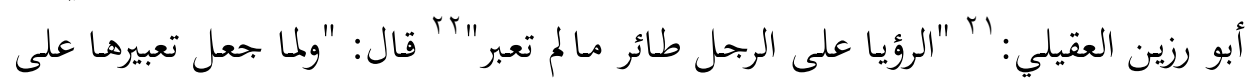

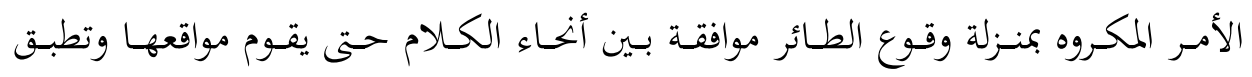

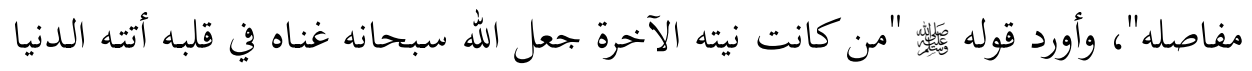

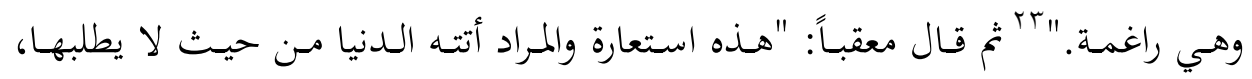

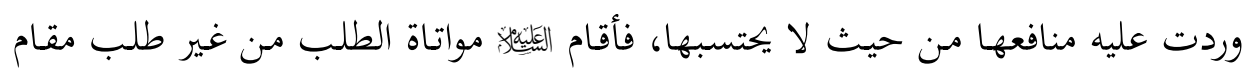

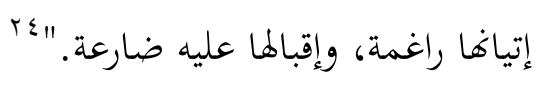

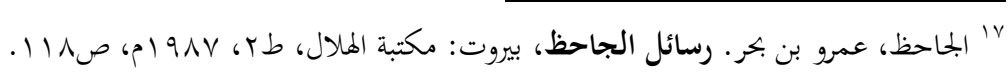

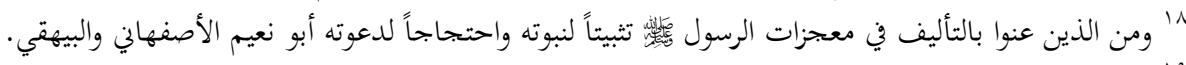

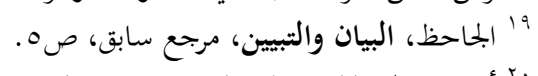

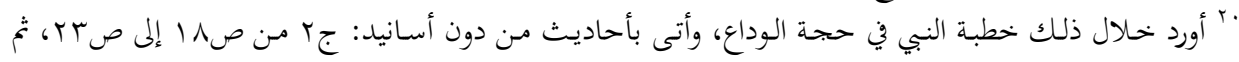

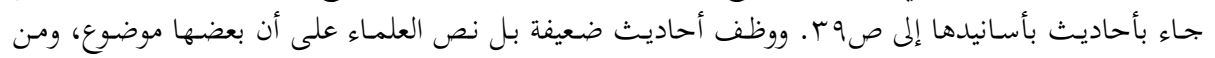

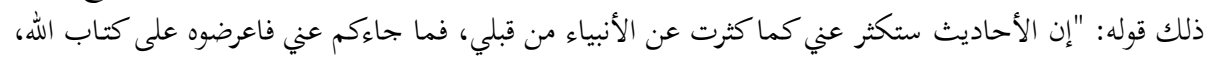

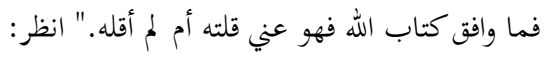

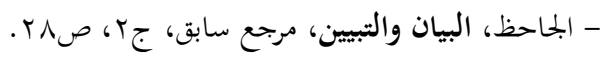

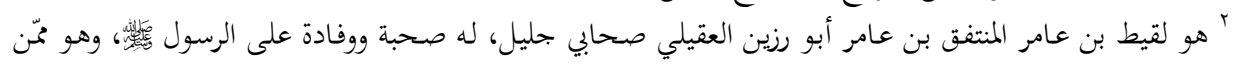

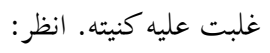

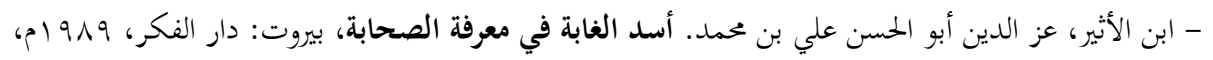

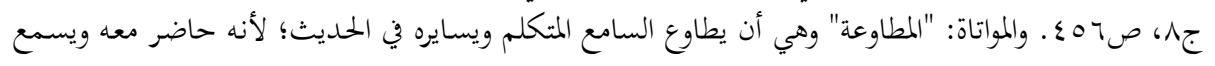

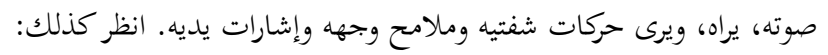

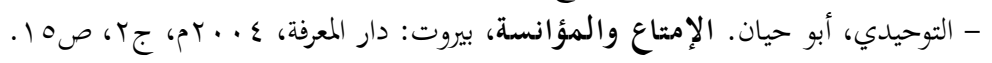

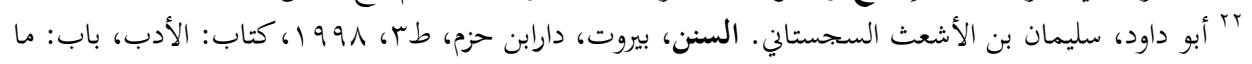

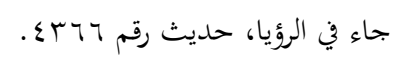

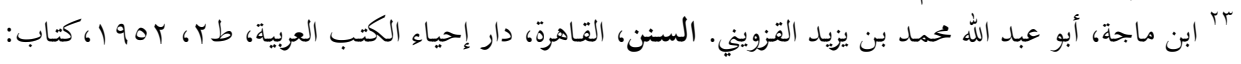

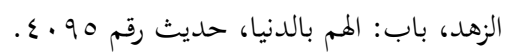

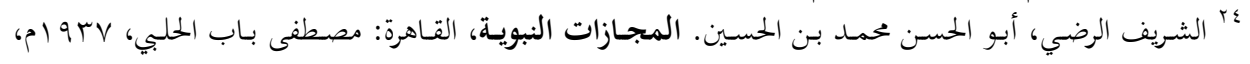




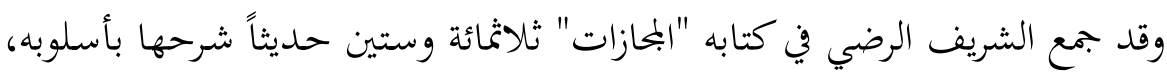

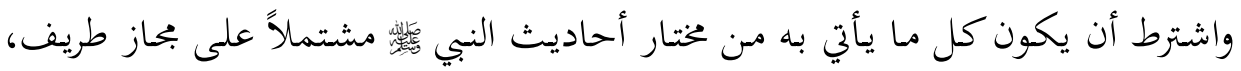

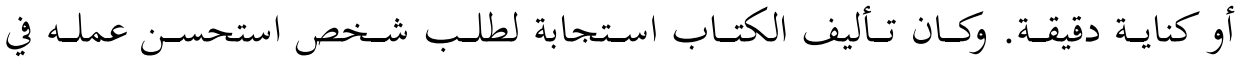

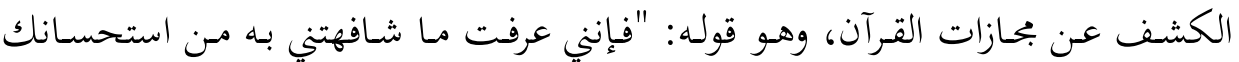

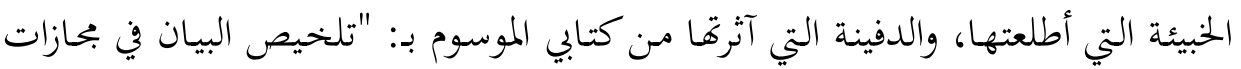

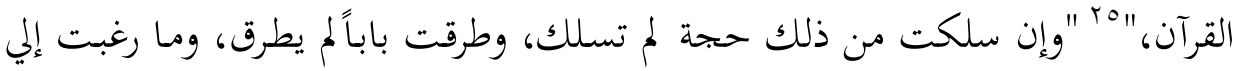

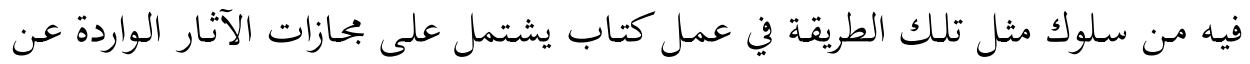

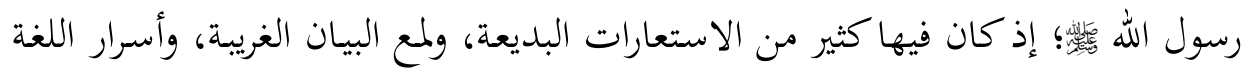

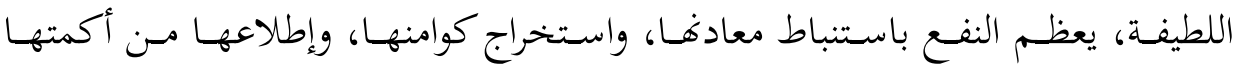

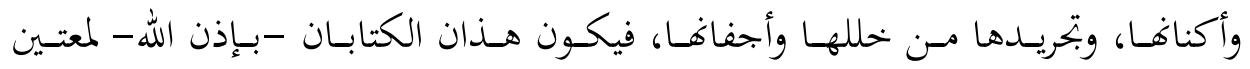

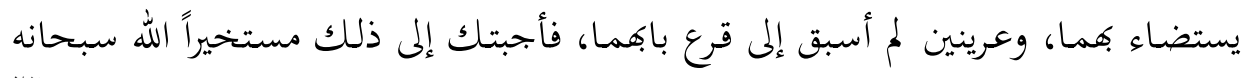

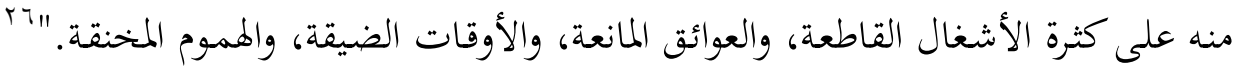

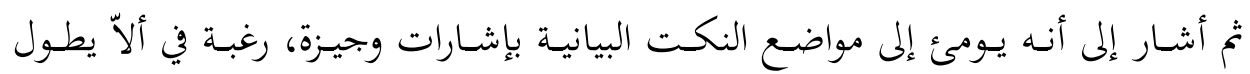

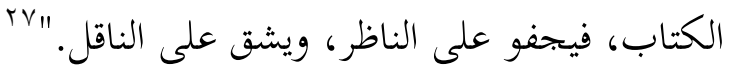

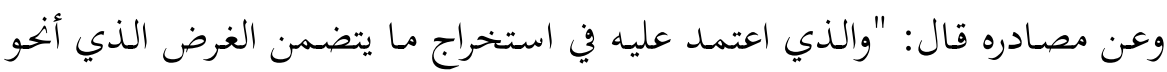

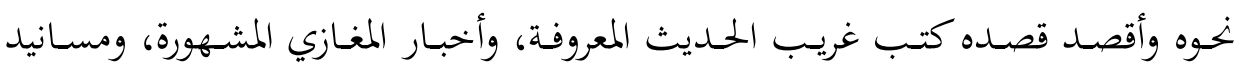

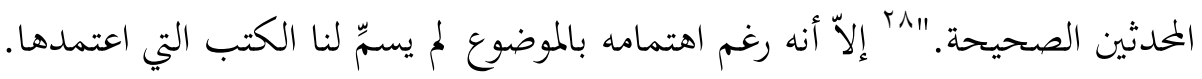
وكتب المغازي ليست مصدرراً من مصادر الحديث، وهي من الكتب التي لم يشدد

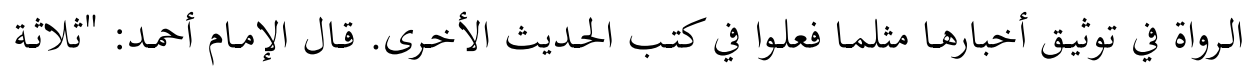

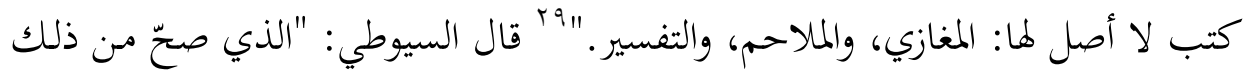

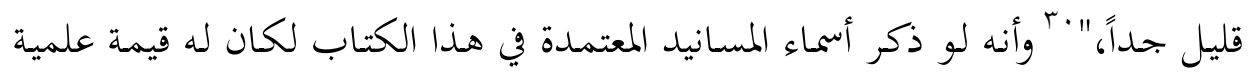

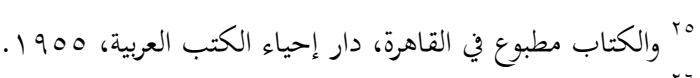

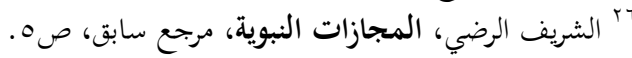

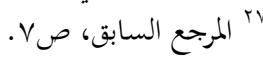

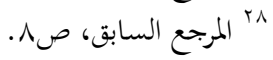

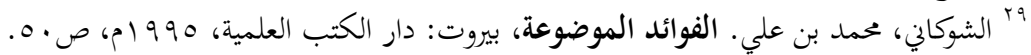

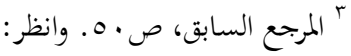

$$
\begin{aligned}
& \text { - البقالي، التناسب البياني في الحديث، مرجع سابق، صوانه : }
\end{aligned}
$$




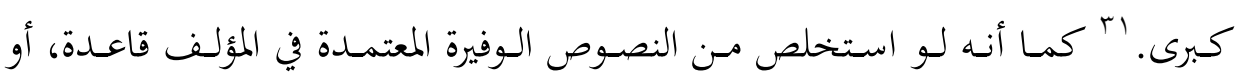

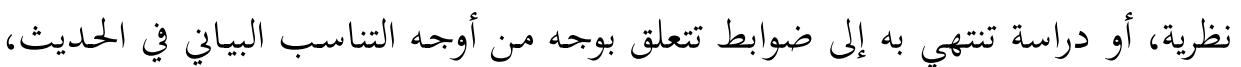

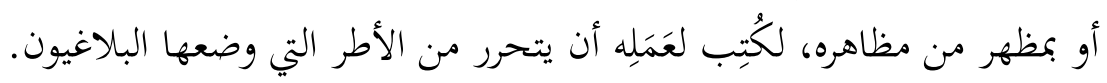

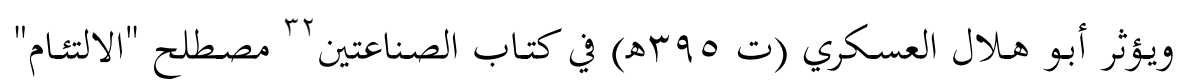

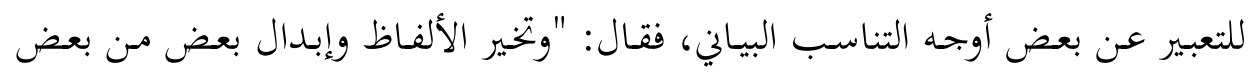
يوجب التئام الكلام، وهو من أحسن نعوته، وأزين صفاته، وإن اتفق له أن يكون موقعه لئه

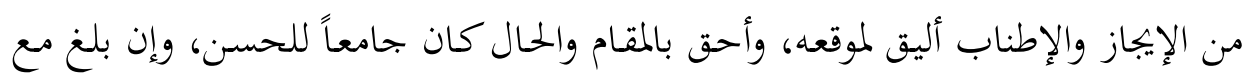

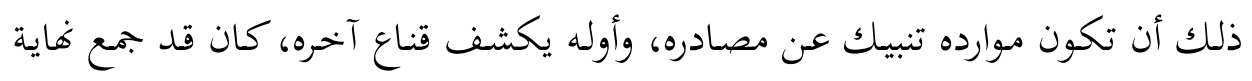

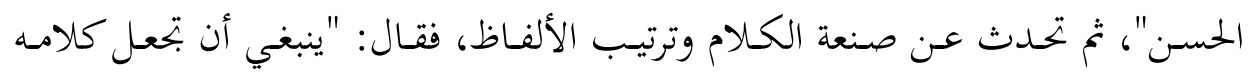

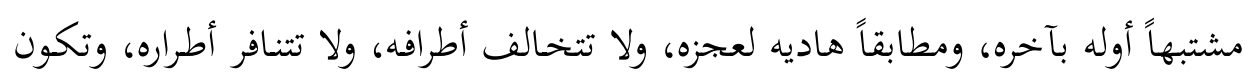

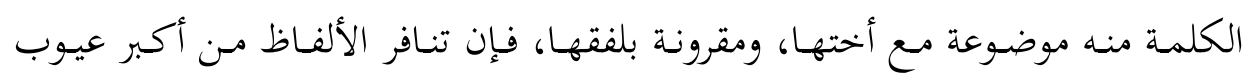

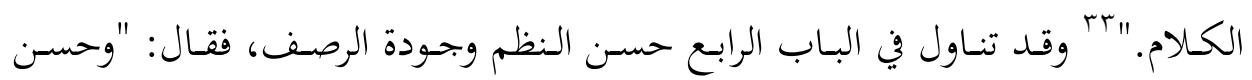

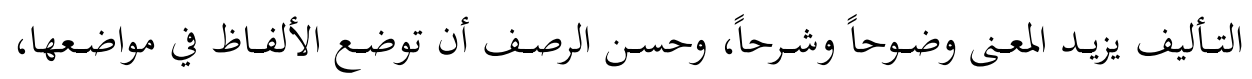

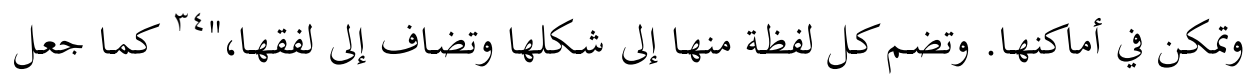

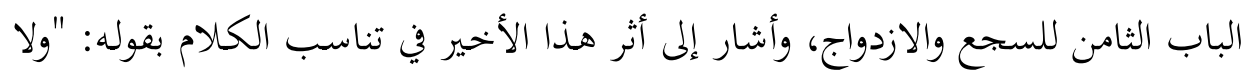

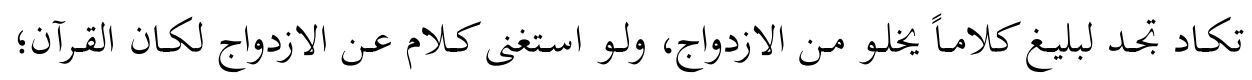

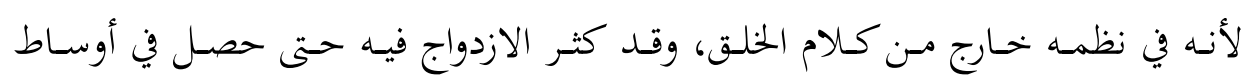

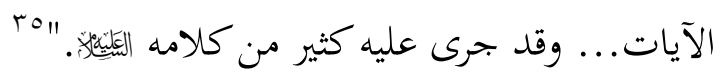

أمـا ابـن رشـيق القـيرواني (ت بآـ هـ) فقـد اعتمـد كثيراً على الحـديث في كتابـه:

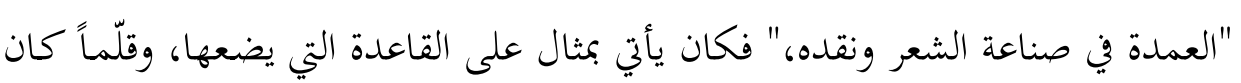

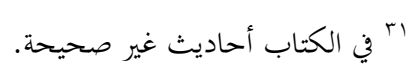

الش

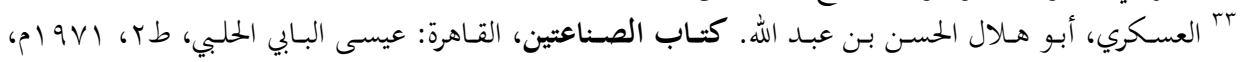

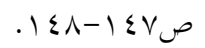

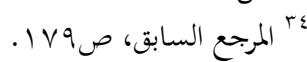

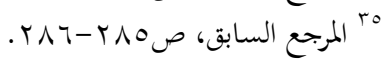




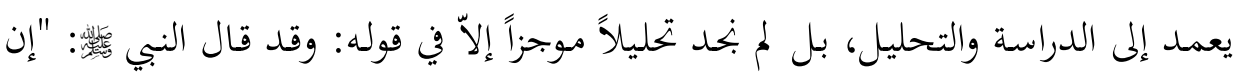

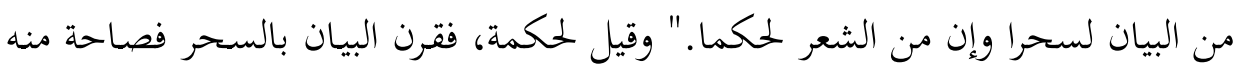

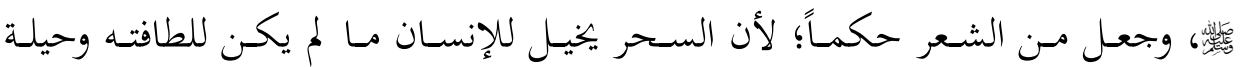
صاحبه، وكذلك البيان يتصور فيه الحـق بصورة الباطل والباطل بصورة الحـق لرقة معنـاه ولطف موقعه. "آr أما في المواضع الأخرى فكان يكتفي بإيراد الحديث واستحسانه، مثل قوله: قـال النبي "كفى بالسـلامة داء،" ومثل هـذا كثير في كلامـهـ

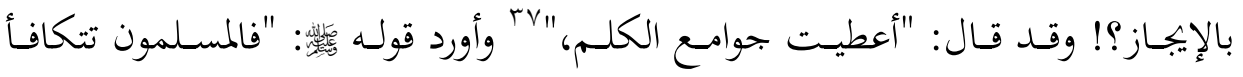
دماؤهم ويسعى بذمتهم أدناهم وهـم يد على مـن سواهم،" "والمرء كثير بأخيه"، وعلق

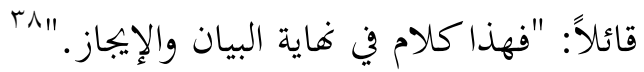

وأشار إلى أثر البحاز في نفس القارئ والسامع، فقال: "والبحاز في كثير من الكالام أبلغ

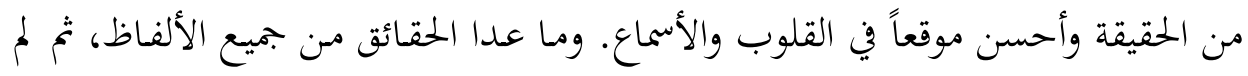

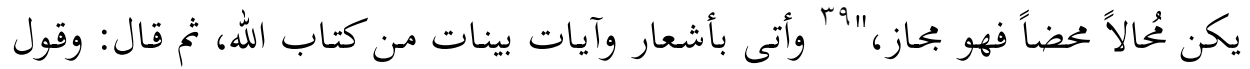

"r ابن رشيق، أبو علي الحسن بن رشيق القيرواني. العمدة في صناعة الشعر ونقده، القاهرة: مكتبة أمين هندية،

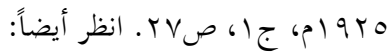

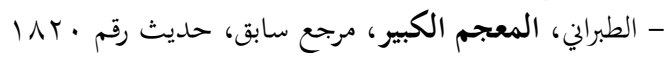

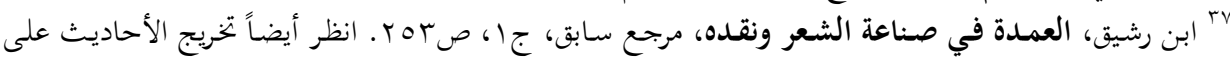
التوالي: - len - القرطبي، أبو عبد الله محمد ابن أحمد الأنصاري، تفسير القرطبي، بيروت: دار الكتاب العربي، 910 (م)، تفسير سورة سبأ، آية أبو عهد. - القضاعي، أبو عبد الله محمد ابن سلامة. مسـند الشهاب، بيروت: مؤسسة الرسالة، ط؟، 919 (م) جه،

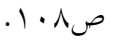
- مسلم، أبو الحسين مسلم بن الحجاج. الجامع الصحيح، بيروت، دار المعرفة، 919 (1م، كتاب: المساجد،

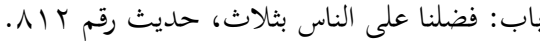

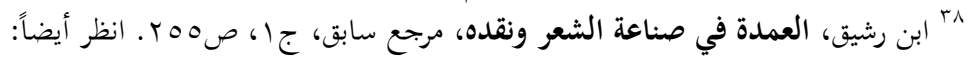

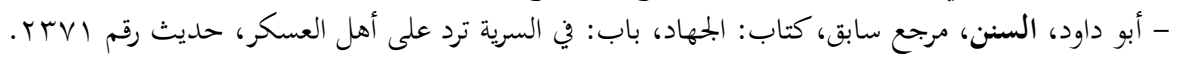

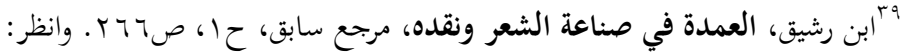

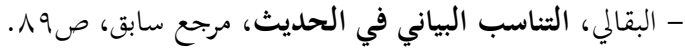




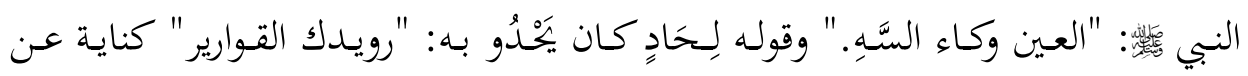

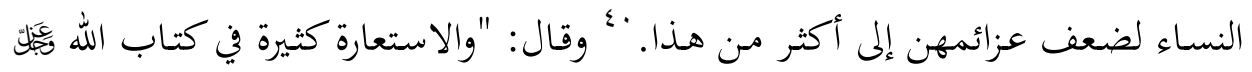

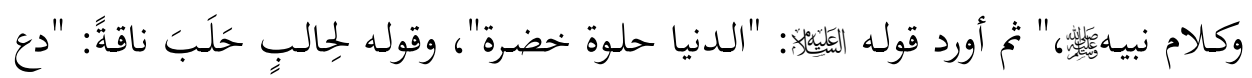
داعي اللبن"؛ أي بقية من اللبن في الحلب، وقوله: "تمسحوا بالأرض فإِها بكم بَرَّة". قال أبو عبيـ: "يريد منها خلقهم وفيها معادهم وهي بعد الموت كفـاقم. "اء وقوله: "رب تقبل توبتي واغسل حوبتي؛" فغسل الحوبة استعارة مليحة. بع وفي مبحث التمثيل استشهـ بأحاديـث عـدّة، مـن ذلك قوله: "الصـوم في الشـتاء الغنيمـة البـاردة"، ومنـه أيضـاً قوله: "ظهر المؤمن مشجبه، وخزانته بطنه، وراحلته رجله، وذخيرته ربه." ومنه: "المؤمن في الدنيا

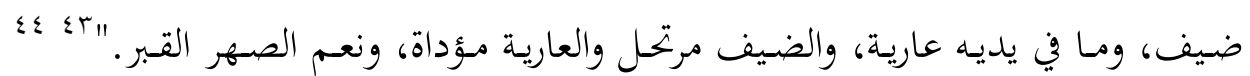
وبعد هذا العرض قال: "وكثير من هذا يطول تقصيه. "ه؛ تم أثنى الحلديث وبلاغتهه بكلام

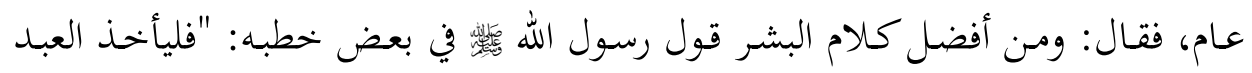

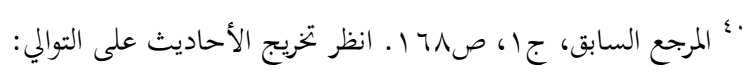

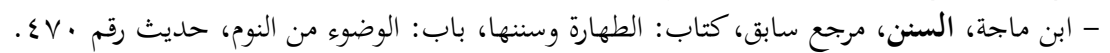

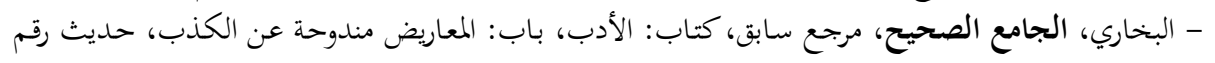

اء الكفات: الموضع يضم فيه الشيء ويجمع. انظر تخريج الأحاديث على التوالي:

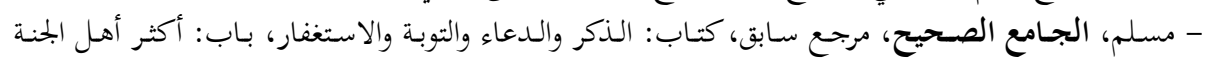

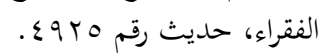

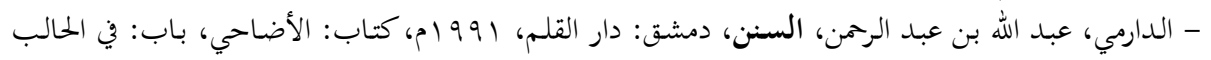

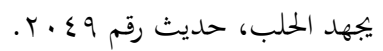

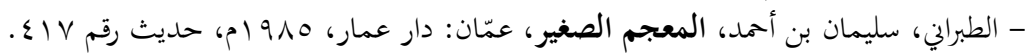

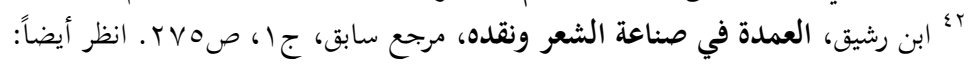

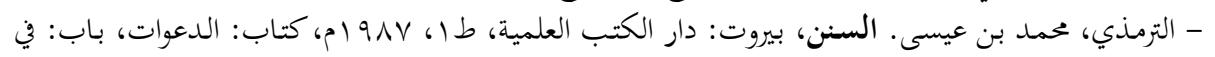

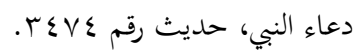

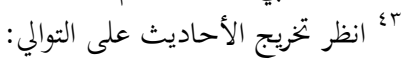

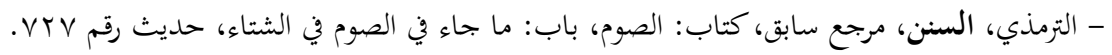

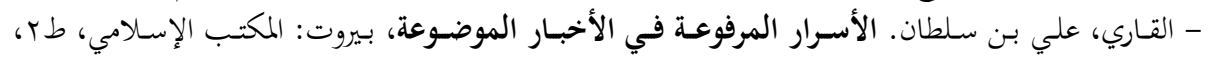

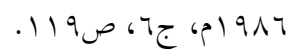

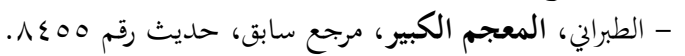

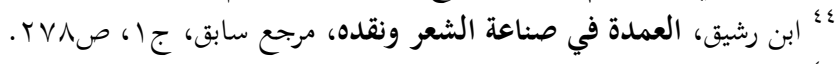

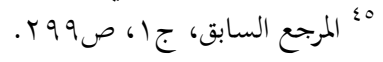


من نفسه لنفسه ومس دنياه لآخرته قبل الكبر، ومـن الحياة قبل الممات، فوالذي نفس

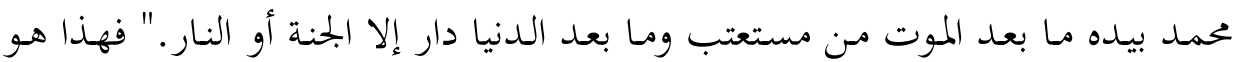

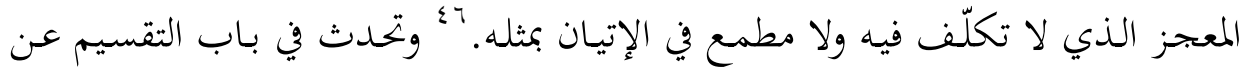
دقة الرسول لد

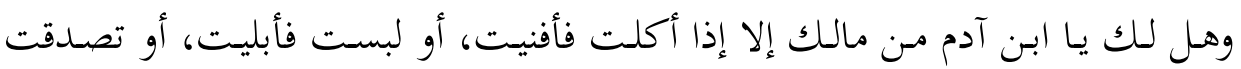

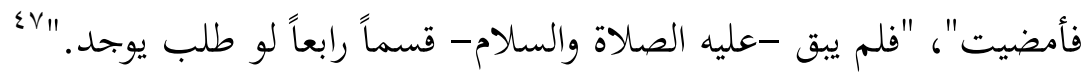
عاصـر ابـن رشـيق عَلَمـاً مـن أعـلام البيـان هـو ابـن سـنان الخفــاجي؛ إذعُرف ابـن

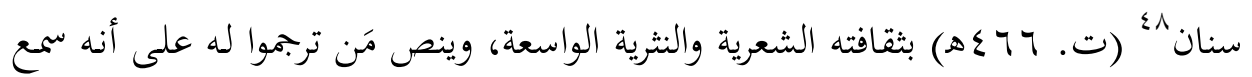

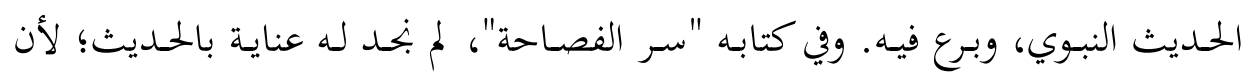
الغرض من تأليفه كان معرفة حقيقة الفصاحة، وقد أورد ذلك في مقدمته: "أما بعد: فإني لما رأيت الناس مختلفين في ماهية الفصاحة وحقيقتها، أودعت كتابي هذا طرفاً من شأها

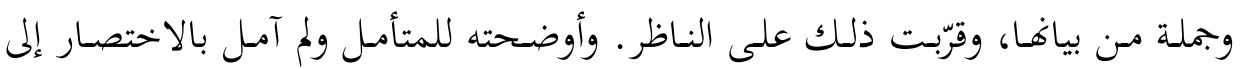

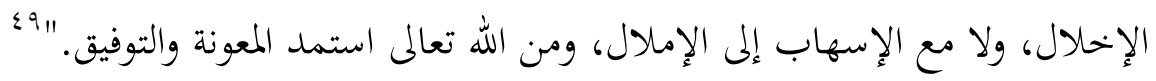

ومن النماذج الدالة من كلام ابن سنان الخفاجي على بعض الأحاديث من وجهة النظر البيانية، قوله في مبحث المزاوجة: " ... حدثني أبو القاسم زيد بن علي الفارسي قال بعل

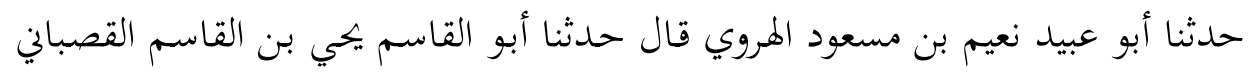
قال حدثنا دعلج بن أحمد قال حدثنا علي بن عبد العزيز البن البغوي قال حدثثنا أبو عبيد

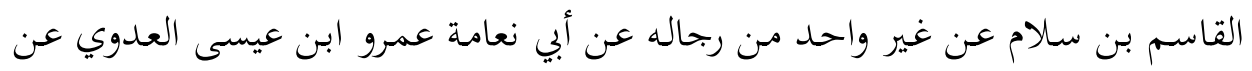

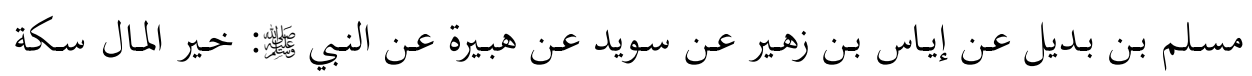

$$
\text { بـ المرجع السابق، / N/ انظر أيضاً: }
$$

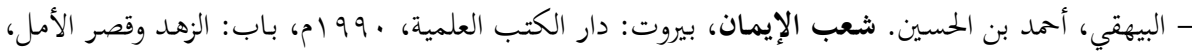

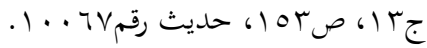

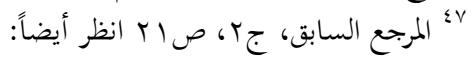

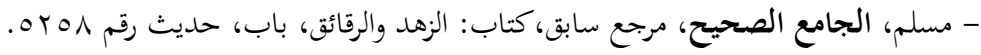

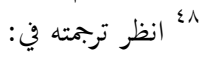

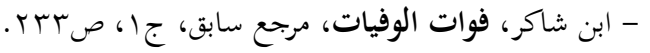

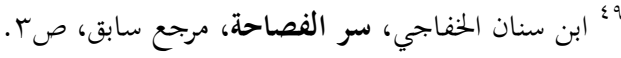


مأبورة، ومهرة مـأمورة". فقـال مـأمورة لأجل المناسبة والمستعمل مـومرة؛ أي كثيرة النتاج

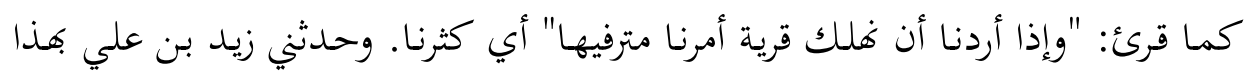

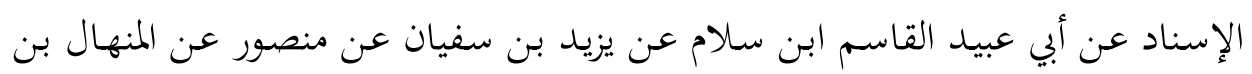

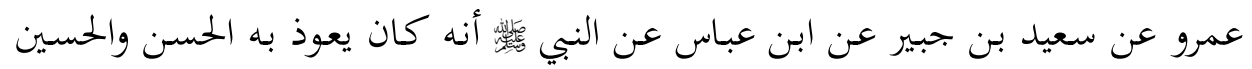

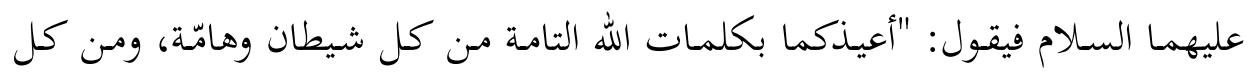

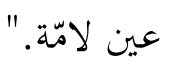

ولم يقل ملمة لأجل المناسبة. وكذلك قوله هئلة في بعض الحديث: "ترجعن مأزورات غير مأجورات، جاء به هكذا؛ لأجل المناسبة؛" ·ه لأن مأزورات من الوزر والمستعمل موزورات فجاء به هكذا من أجل المناسبة. ونخلـص إلى أنـه جعـل للصـياغة اللفظيـة مكانـة مرموقـة؛ إذ يـرى أن أسـرار روعـة

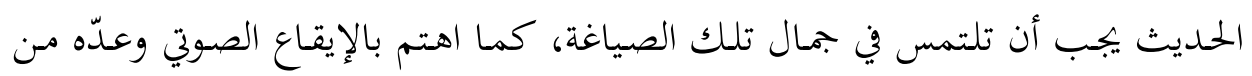
أسباب روعـة الحـديث. وقـد ضمّن كتابه "سـر الفصـاحة" مباحـث بلاغيـة تنـاول فيها العناصر الإيقاعية؛ كالتلاؤم، والفواصل، وتناسب المقدار، والترصيع. ومن العلماء الذين اهتموا بالحديث وشهدوا بتناسبه أبو حيان التوحيدي، 'ه مالذي

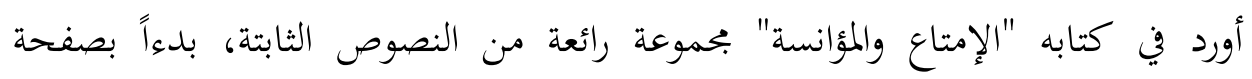

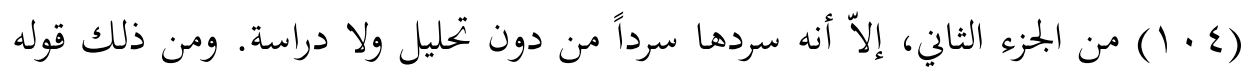

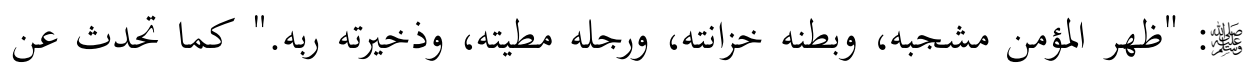

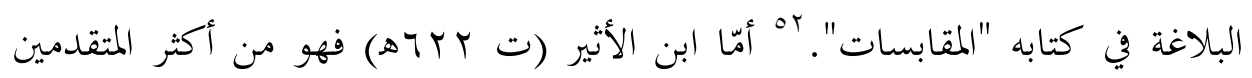

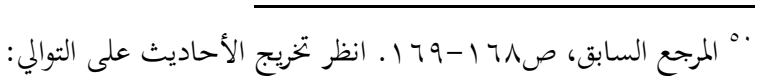

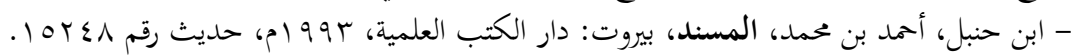

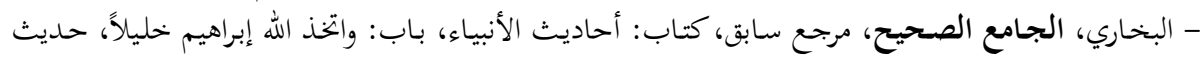

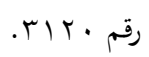
- ابن ماجة، السنن، مرجع سابق، كتاب: ما جاء في الجنائز، باب: ما جاء في اتباع النساء الجنائز، حديث رقم $107 \mathrm{~V}$

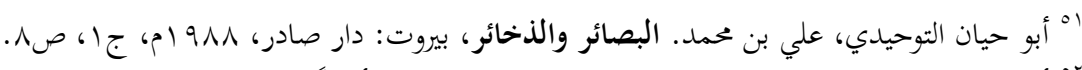

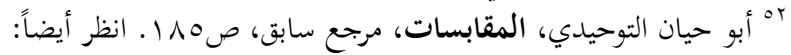

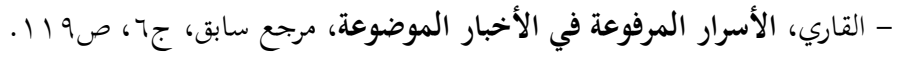


عناية بالحديث؛ إذ يرى أن قراءته وتذوقه يكسِب المرء قدرة على الكتابة والاستشهاد

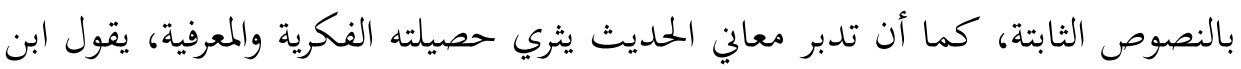

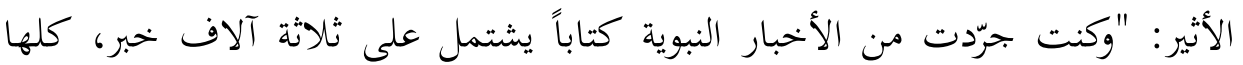

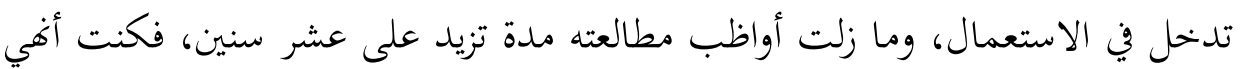
مطالعته في كل أسبوع مرة، حتى دار على خحاطري وناظري ما يزيد على خمسمائة مرة

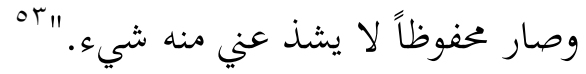

ويلاحظ المتتبع لكتابه الواقع في جزأين أنه عني بالحديث، فقد درسه من الوجهة البلاغية، لكن ما كتبه عنه كان بحرد تعليقات عامة تدل على حبه واستحسانه للكلمة

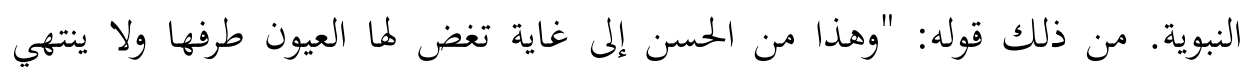

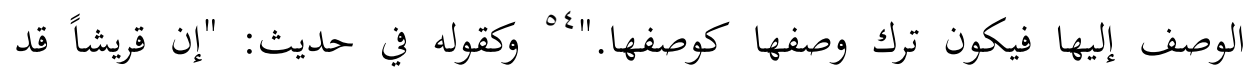
هكتهم الحرب. " وهذا الحديث من جوامع الكلم، وهو من "الفصاحة والبلاغة على غاية

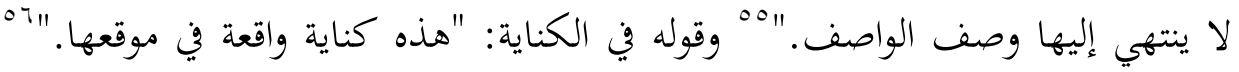

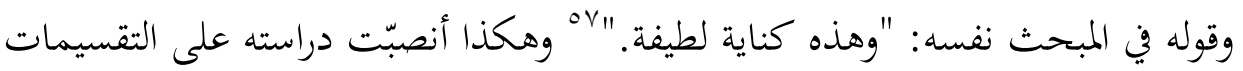
التي وضعها البلاغيون من قبل، كالتشبيه: المركب، والعقلي، والحسي، وابن الأثير يورد

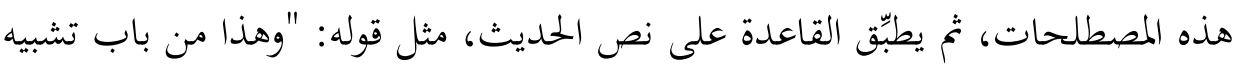

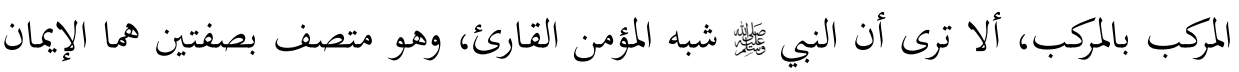

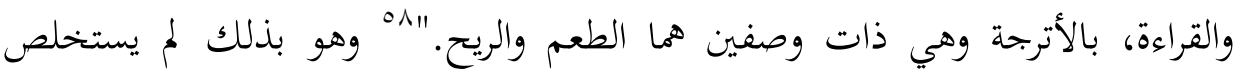
أوجهاً للتناسب البياني في الحديث، أو مظهراً من مظاهره، بصورة تفيد دارسي الحمديث. وخلاصة القول إن موضوع التناسب الحميثي لم يحظ باهتمام علماء البيان، وقبلهم

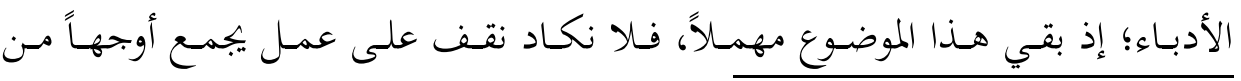

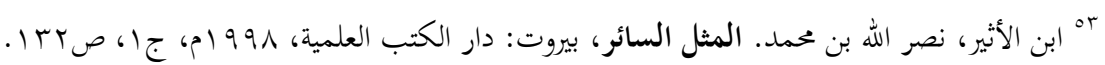

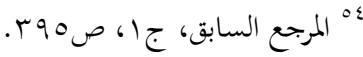

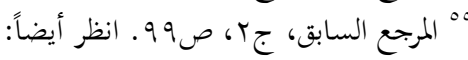
- البخاري، الجامع الصحيح، مرجع سابق، كتاب: الشروط، الباً: باب: الشروط في الجهاد والمصالحة، حديث رقم 
التناسب البياني في الحديث، ويبيِّن قيمة هذا المبدأ الجمالي الواسع. ويدعم هذا الرأي ما

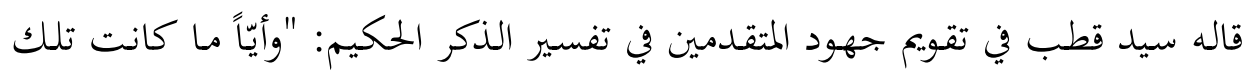

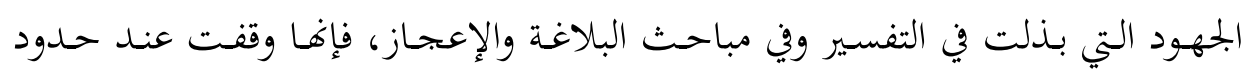
عقلية النقد العربي القديمة، تلك العقلية الجزئية التي تتناول كل نص علئ على حِدَة، فتحلله

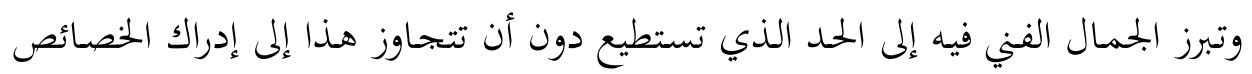

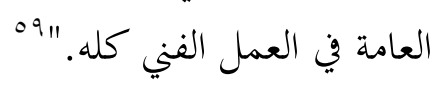

\section{ثانياً: التناسب في الدراسات الأدبية الحديثة}

قامت في العصر الراهن محاولات جادة لدراسة البيان في الحديث النبوي الشريف،

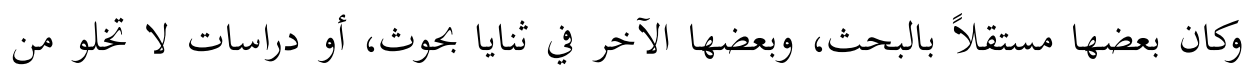

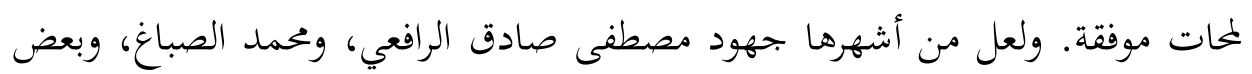

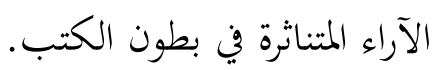

\section{I . جهود مصطفى صادق الرافعي (ت צه I اه):}

خصّ الرافعي الجزء الثاني من كتابه "تاريخ آداب العرب" لموضوع إعجاز القرآن

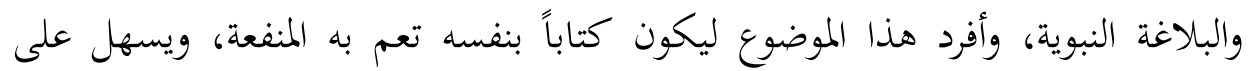

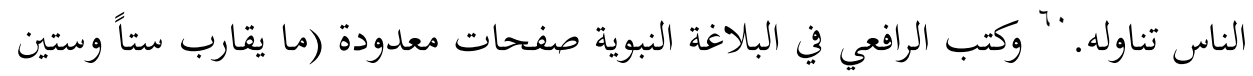

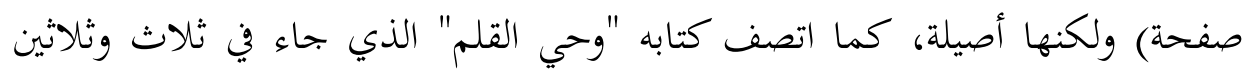
صفحة بجزالة اللفظ وقوة النسج. وقد تحدث في الكتاب الأول عن البلاغة الإنسانية، ثم أوضح أن فصاحته

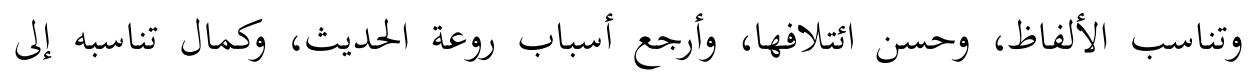

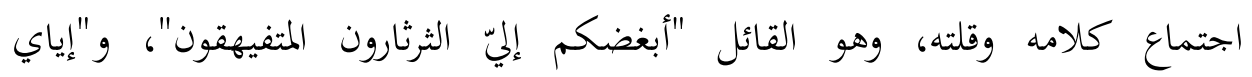
والتشادق.

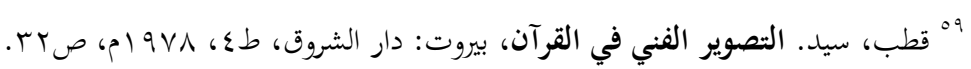

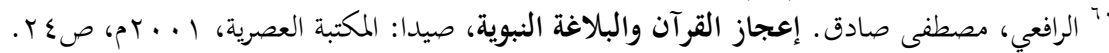

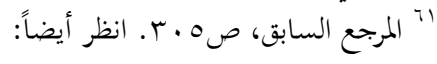


وهذا النص هو ما قاله في مستهل حديثه عن البلاغة النبوية: "ألفاظ النبوة يعمرها

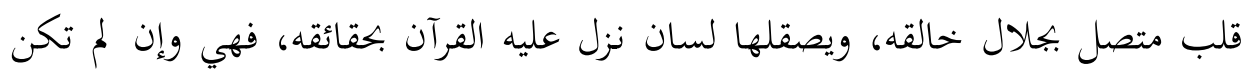

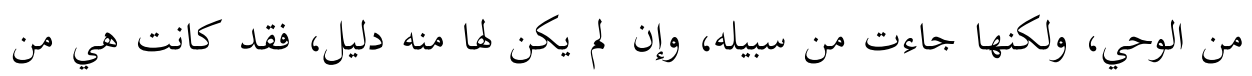
دليله، محكمة الفصول، حتى ليس فيها عروة مفصولة، وكأما هي في اختصارها وإفادها

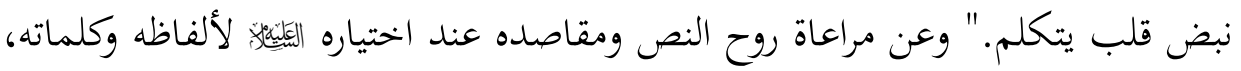

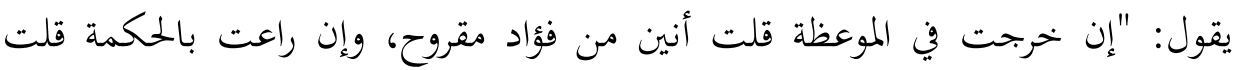

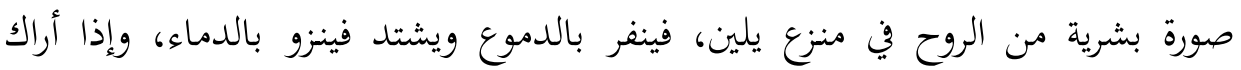

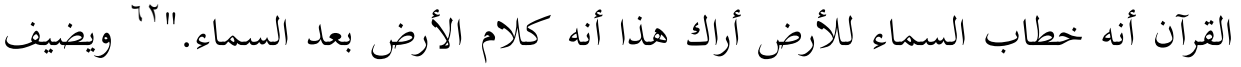

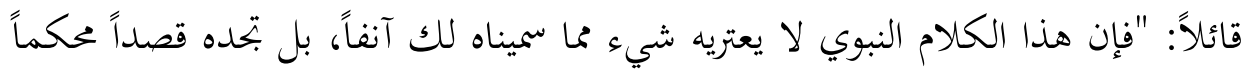

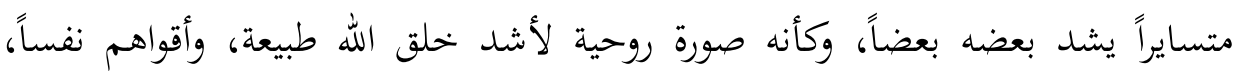

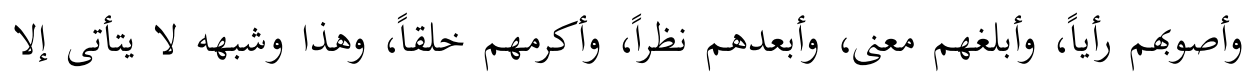

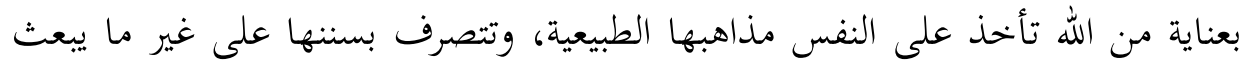

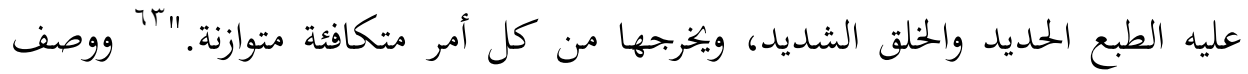

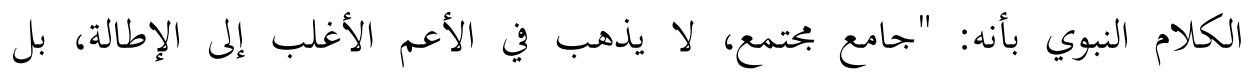

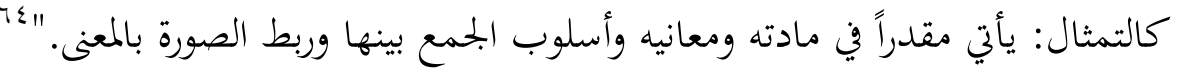
ويرى الرافعي أن الكالام النبوي أثّّ في الأوضاع التركيبية أو في التركيب البياني،

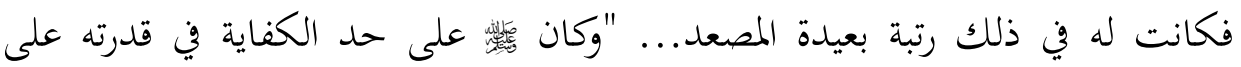
الوضع، والشقيق من الألفاظ، وانتزاع المذاهب البيانية، حتى اقتضب ألفاظاً كثيرة لم

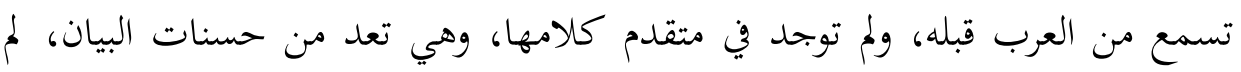

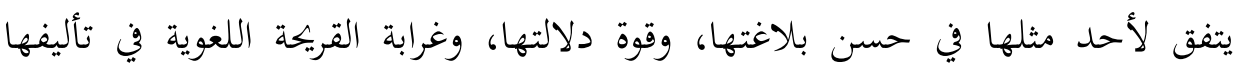

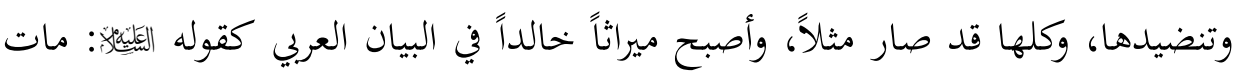
حتف أنفه.

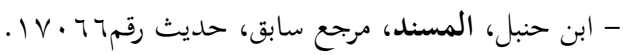

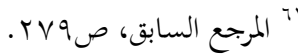

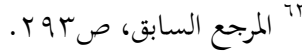

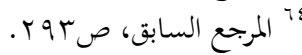

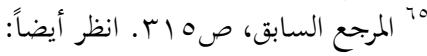


وذهب إلى قلة كلامه واجتماعه فقال: "وضرب آخر من الأوضاع التركيبية في بلاغة

النبي

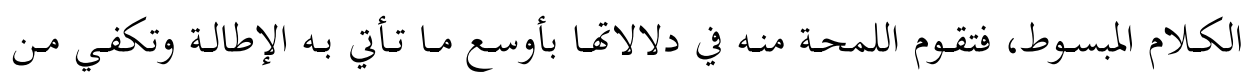

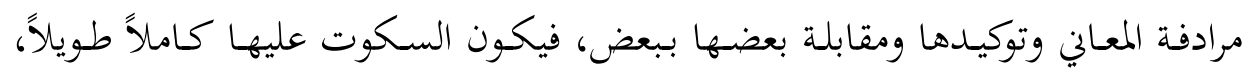

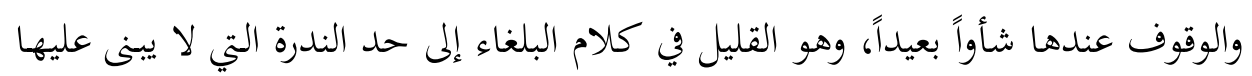

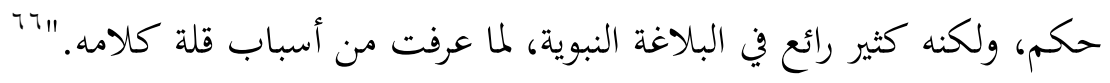

\section{أ. تناسب المعاني عند الرافعي:}

تحدث الرافعي عن هذا الجانب بشكل مقتضب، ويبدو أنه اعتمد في كلامه عن التناسب البياني في الحديث على كتابات الجاحظ، والشريف الرضي، وابن الأثير. وفي

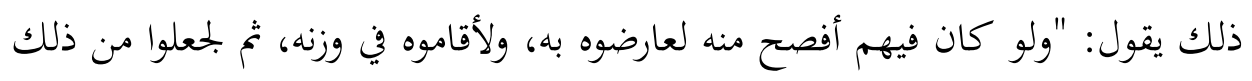

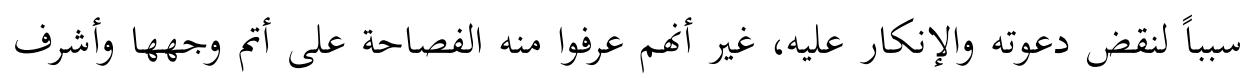

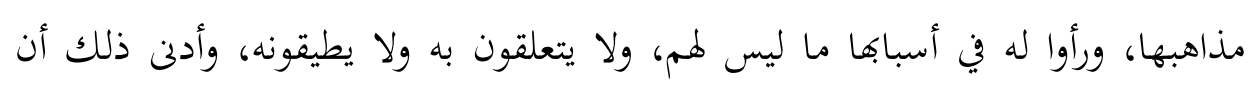

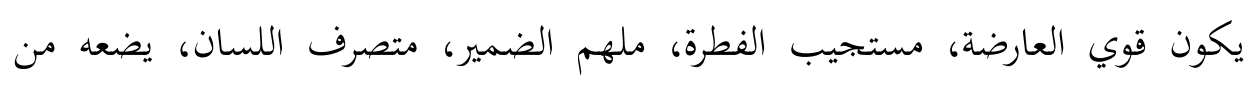

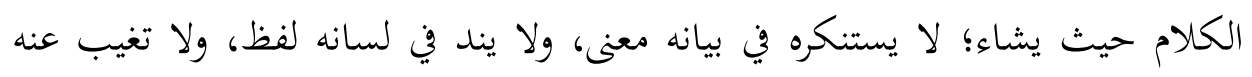

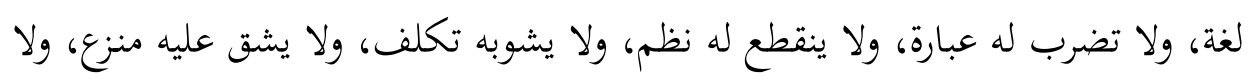

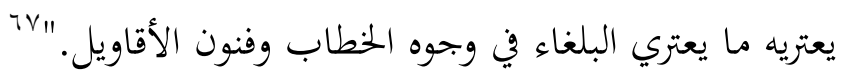
تم عرض للعيوب التي تشوب كلام البلغاء قائلاً: "لا نرى العرب قد أقروا له

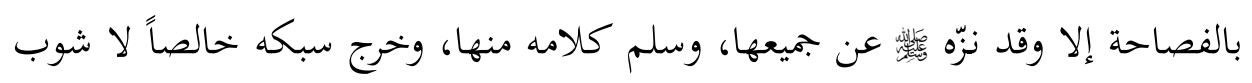

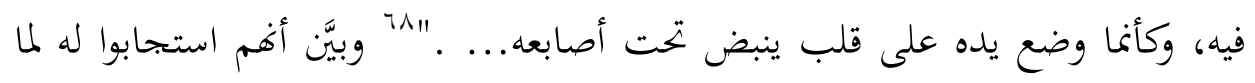

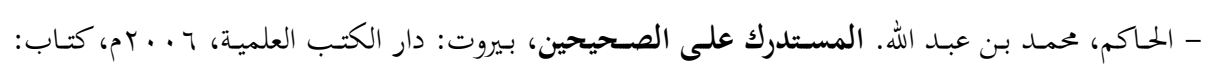

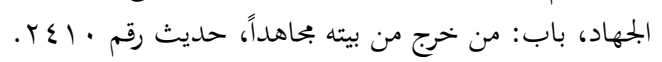

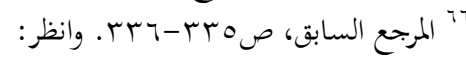

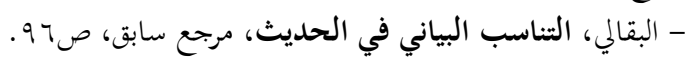

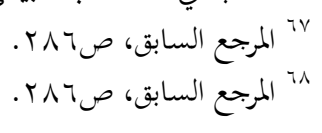


خص به من الفصاحة وحسن البيان، بقوله: "فإن القوم خلص لا يستجيبون إلا

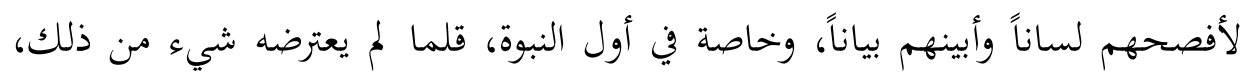

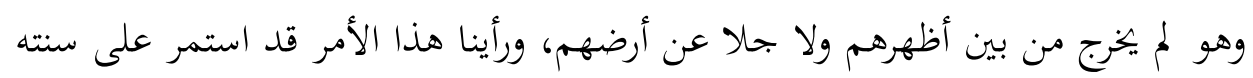

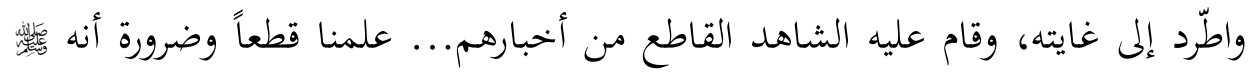

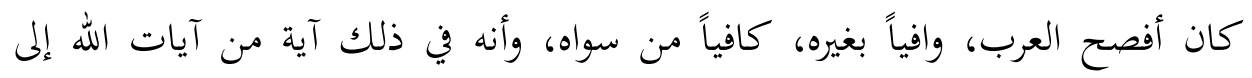

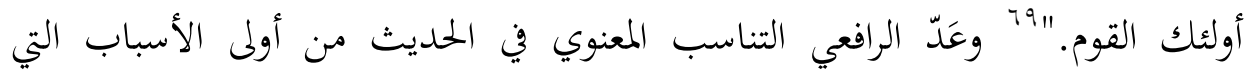

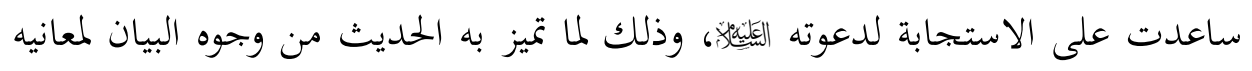

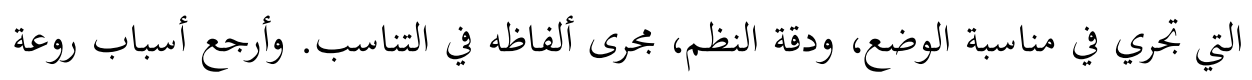

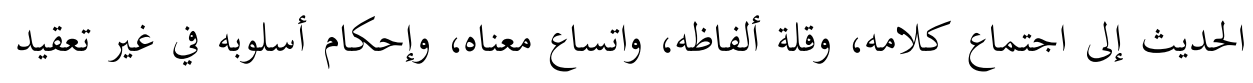

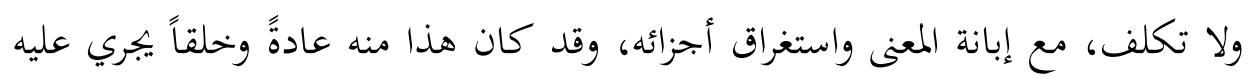

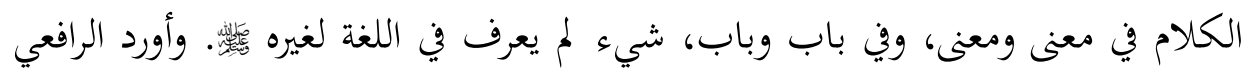

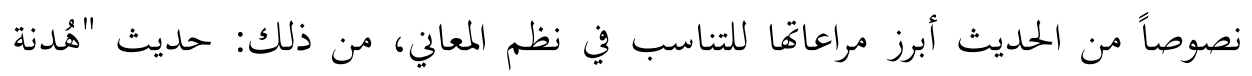

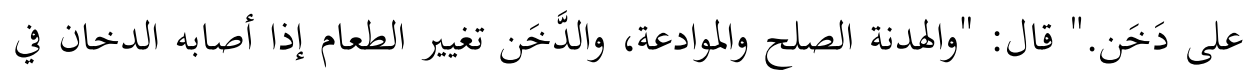

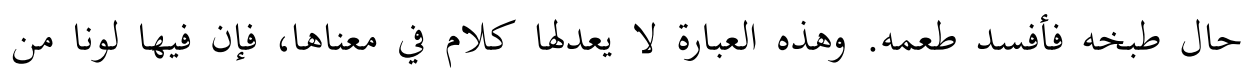

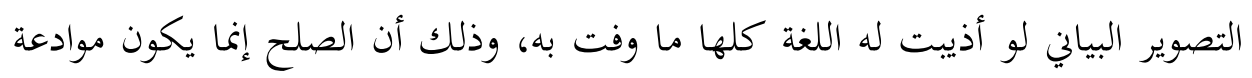

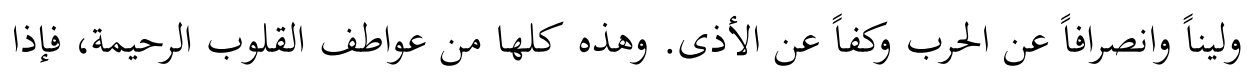

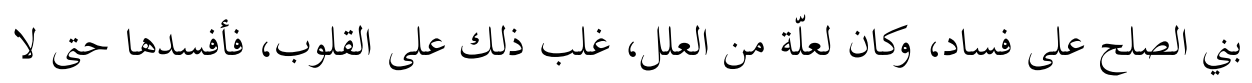
يستروح غيره من أفعالها، كما يغلب الدخن على الطعام فلا يجد آكله إلا رائحة هذا

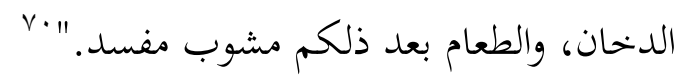

فهذا في تصوير معنى الفساد الذي تنطوي عليه القلوب الواغرة. وثمة لون آخر في صفة هذا المعنى، وهو اللون المظلم الذي تنصبغ به النية "السوداء"، وقد أظهرته في تصوير الكام لفظة "الدخن". تمخ معنى ثالث، وهو النكتة التي من أجلها اختيرت هذه اللفظة بعينها، وكانت سرّ البيان في العبارة كلها، وبها فضلت كل عبارة تكون في هذا

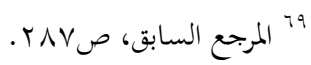

$$
\begin{aligned}
& \text { • لمرجع السابق، ص. . . r. }
\end{aligned}
$$


المعنى، وذلك أن الصلح لا يكون إلا أن تطفأ الحرب. فهذه حرب قد طفئت نارها بما

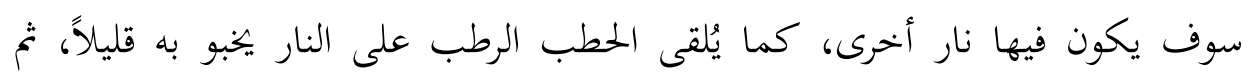

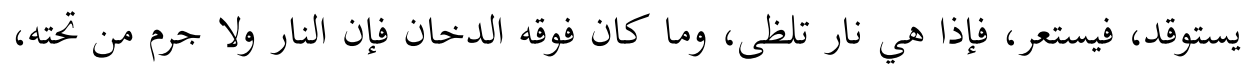

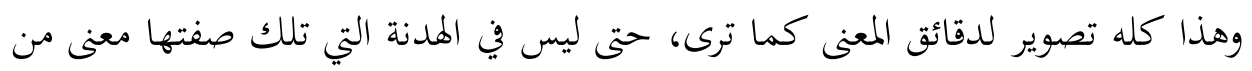

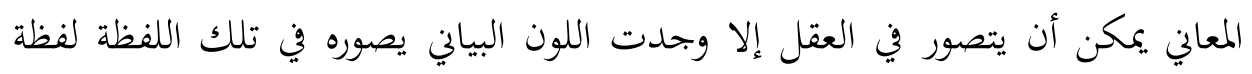
"الدخن.

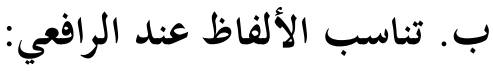

تحدث الرافعي عن تناسب الألفاظ في النظم الحديثي، ضمن حديثه عن صفات

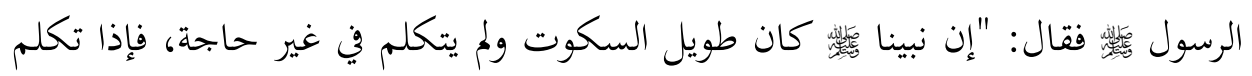

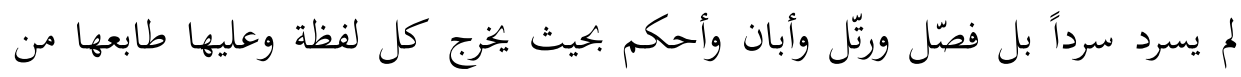

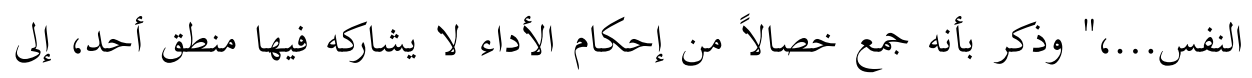

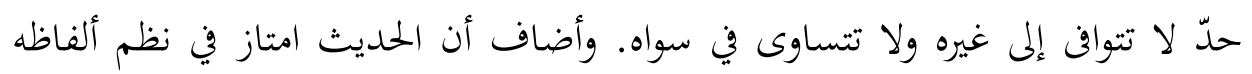

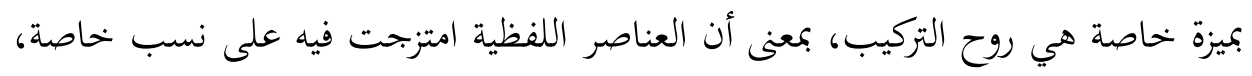

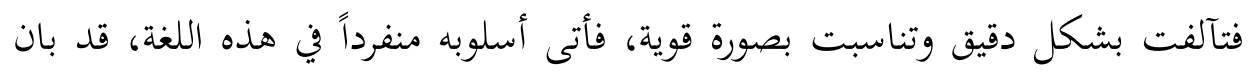
من غيره بأسباب طبيعية فيه.

ورأى أن تخيّر ألفاظ الحديث هو سرّ البيان في جملة التركيب. فمن ذلك قوله الئلغنّا:

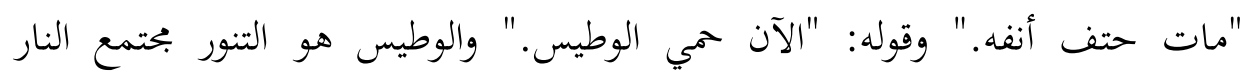

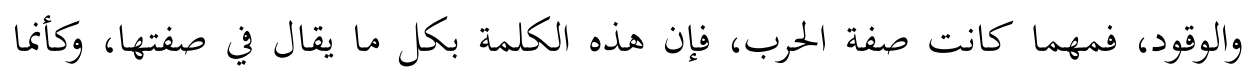
هي نار مشبوبة من البلاغة تأكل الكلام أكلا، وكأنما هي تمثل لك دماء لكاء نارية أو أو ناراً

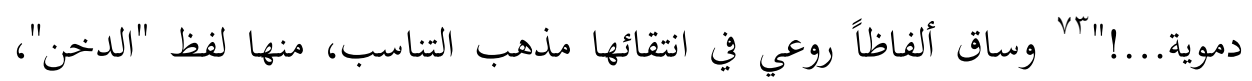

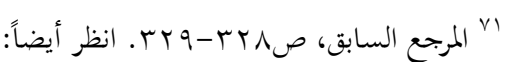

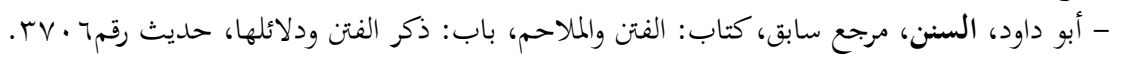

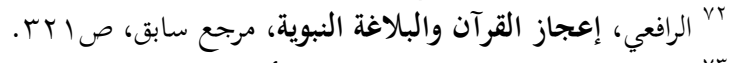

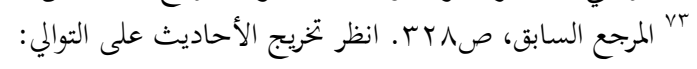




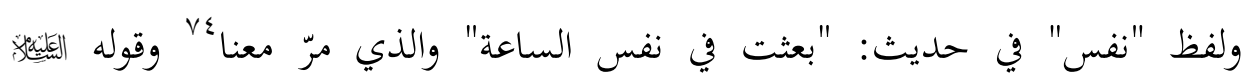
لأبخشة، وكان يسير بالنساء في هوادجهن وهو يمدو بالإبل وينشد القريض والرجز، فتنشط وبحد وتنبعث في سيرها فتهتز الهوادج وتضطرب النساء اضطراباً شديداً "رويدك رفقاً بالقوارير." وقوله في يوم بدر: "هذا يوم له ما بعده." وعلّق قائلاً: لو أردنا أن

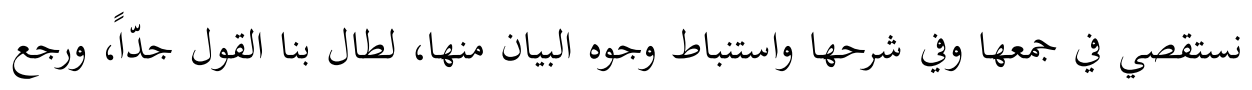
أمر هذا الفصل أن يكون في معنى التأليف كتاباً برأسه، إن كنا لا نلتزم إلا جهة البيان

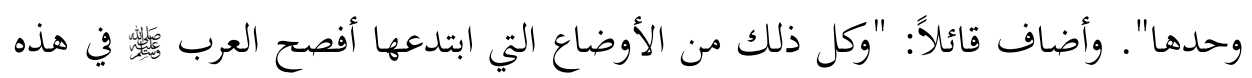
اللغة ابتداء ولم تسمع من أحد قبله، ولا شاركه في مثلها أحد بعد، وكل كلمة منها كما رأيت لا يعد لها شيء في معناها، ولا يفي بها كلام في تصوير أجزاء هذا المعنى وانتظام هذه الأجزاء ونفض أصباغها عليها، وهذا الضرب من الكلام الجامع هو الذي يمتاز البليغ في كل أمة بالكلمة الواحدة من مثله أو الكلمتين، أو الكلمات القليلة القليلة، لو ذهبت تحصيه في العربية ما رأيته إلا معدوداً... vo"

ويبدو أن النهج الذي سلكه الرافعي في دراسة التناسب اللفظي والصوتي يقوم على

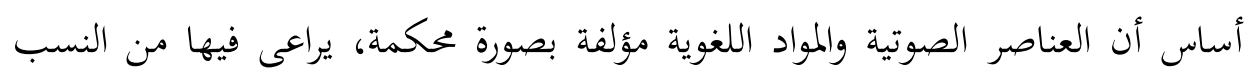
والمقادير يجعلنا نحسّ روعة الموسيقى ومرونتها. وقد ربط الرافعي في هذا الجانب بين تناسب الأصوات، وجمال الصوت وحسن الداء، ميّا يضفي على الكلمة النبوية وضعاً خاصاً يخدم المعنى ويقود إليه. يقول في ذلك: "إن الفصاحة راحة إلى حسن الملاءمة بين الحروف باعتبار أصواتا ومخارجها، حتى تستوي في تأليفها على مذاهب الإيقاع - الحاكم، المستدرك على الصحيحين، مرجع سابق، كتاب: الجهاد، باب: من خرج من بيته بحاهداً، حديث

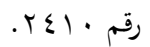

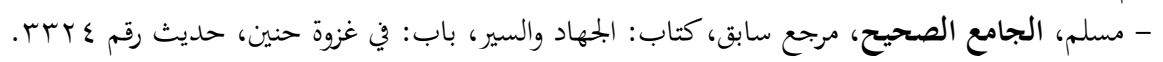

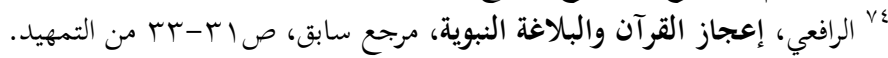

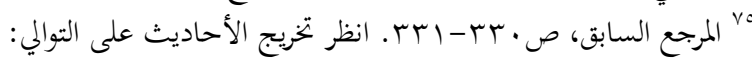

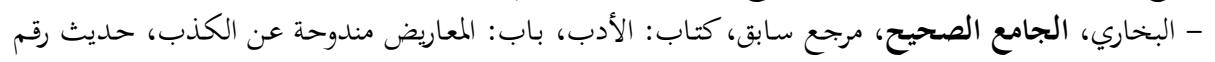
.0V 1 r - ابن حنبل، المسند، مرجع سابق، حديث رقم 0011. 


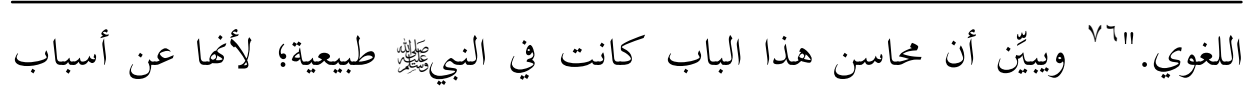

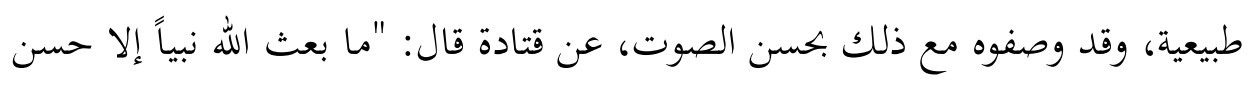

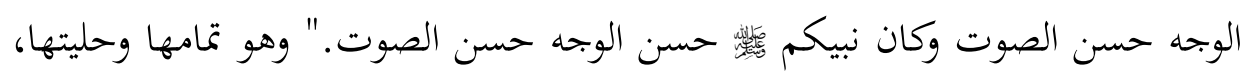

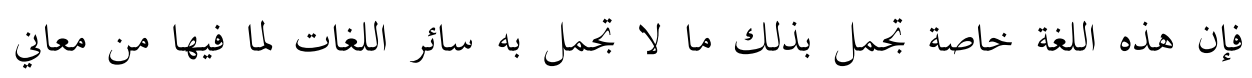
الأوضاع الموسيقية في خفة الوزن، وصحة الاعتدال، وتمام التساوي، وحسن الملاعمة، فلا

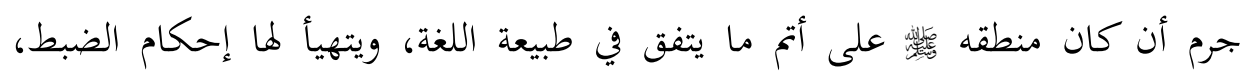
وإتقان الأداء. لفظ مشبع ولسان بليل، وبتحيد فخم، ومنطق عذب، وفئ وفصاحة متأنية، ونظم متساوق، وطبع يجمع ذلك كله، مع تثبت، وتحفظ، وتبيّن، وترسّل، وترتيل. وبعد ذلك ذكر حديث السيدة عائشة رضي الله عنها: "ما كان رسول الله يلّئ يسرد كسردكم هذا، ولكن كان يتكلم بكلام بيّن فصل، يهفظه من جلس إليه." وفي رواية

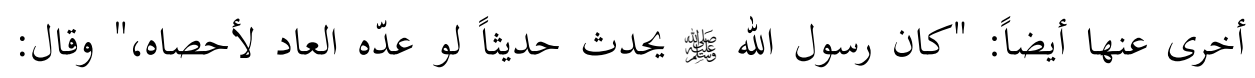
"وليس إحكام الأداء وروعة الفصاحة وعذوبة المنطق وسلاسة النظم إلا صفات كانت فيه ئس المناسب بحيث تخرج كل لفظة، وعليها طابعها من النفس وهو بذلك قد جمع خصالاً

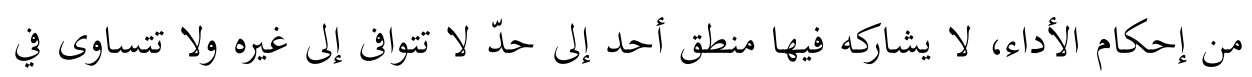
سواه. ويُعَدّ الرافعي أول مَن أولى اهتماماً بقيمة الأصوات اللغوية، وجمال نظمها؛ إذ أحس بقيمتها في جمال الكلمة النبوية، كما استشعر روعة الموسيقى في النظم الحمديثي المتوازن في العبارة الذي يصاحب المعنى مصاحبة واعية، ومن أجل هذا كانت كتاباته ذات تأثير قوي في مَن عاصروه من المهتمين بالبلاغة النبوية، أو بأوجه من التناسب الحديثي.

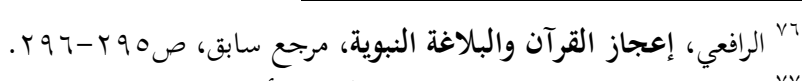

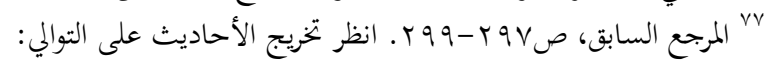

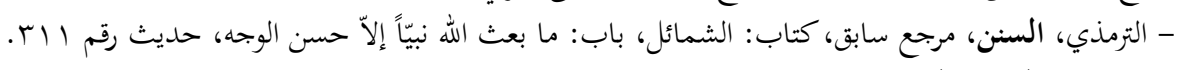

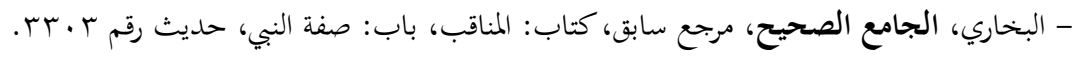




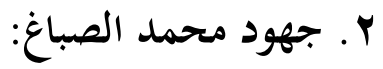

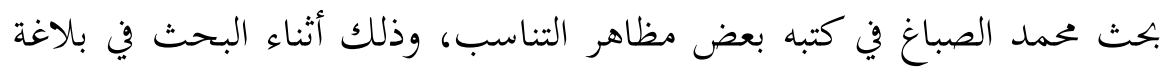

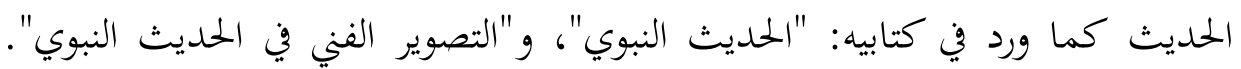

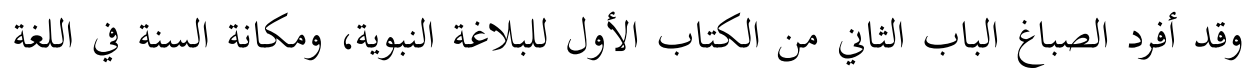

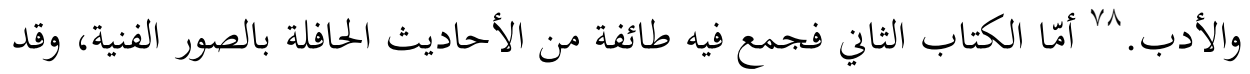

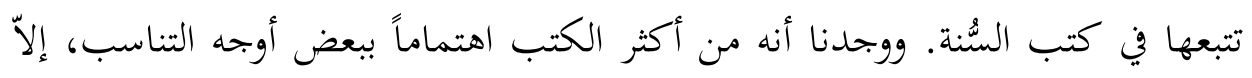

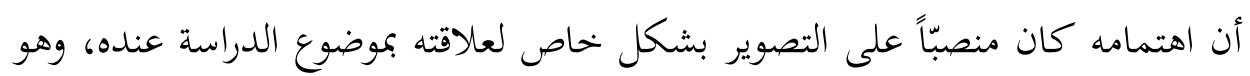

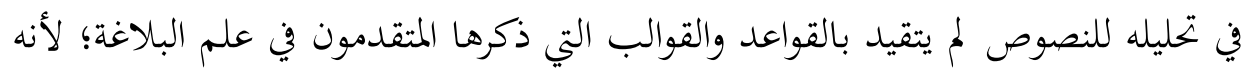

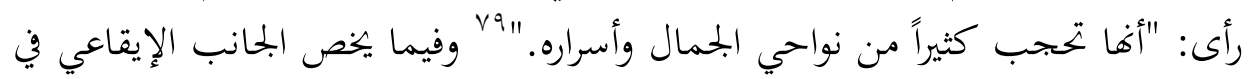

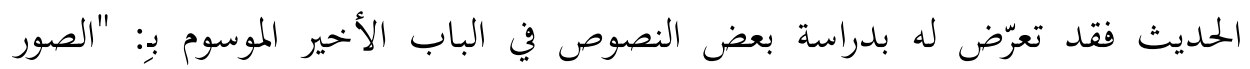

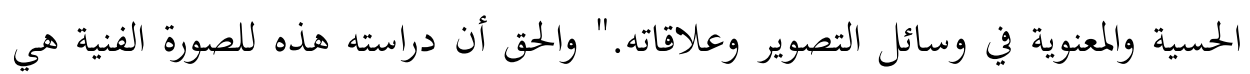

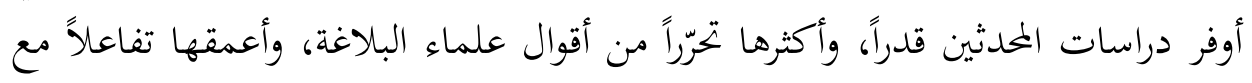
نصوص السُنة الجميلة.

\section{ثالثاً: تناسب الأصوات في نظم الحديث}

\section{1. التناسب الصوتي في النظم الحديثي:}

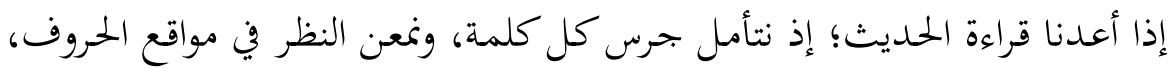

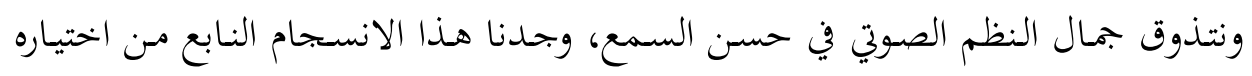
ئس المواده اللفظية ذات النبرات الموسيقية العذبة والإيقاع الفريد.

فكل كلمة تثير بجرسها معاني شتى، وتصوّر ما ينبغي للإنسان فعله، وما يتعيّن عليه

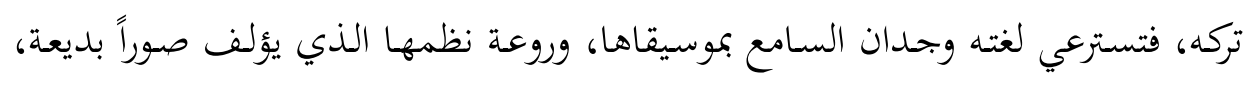

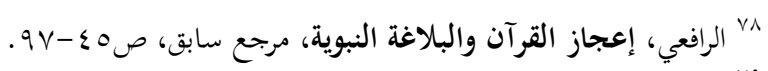

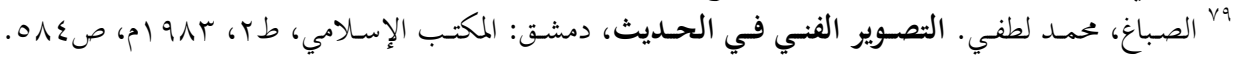
وانظر: - البقالي، التناسب البياني في الحديث، مرجع سابق، صبr ا. 
ولا يعتمد على الكلمات المفردة في جمال إيقاعه؛ ذلك أنه قد تكون الكلمة مقبولة في

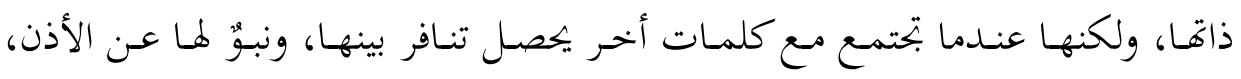

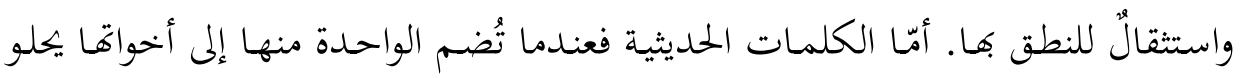
جرسها، وتزيد عذوبتها، ويحسن إيقاعها.

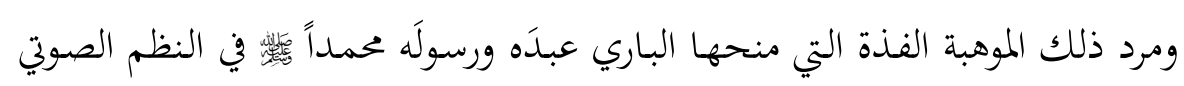
الموسيقى للحديث، والتآلف المدهش بين مخارج الحروف؛ إذ لا نرى ازدحاماً لحرف ثنيل

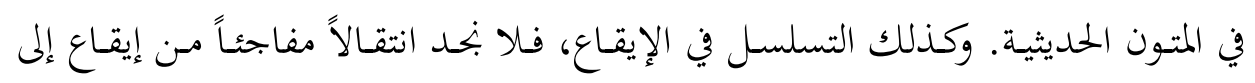
آخر إلاّ إذا تطلب المضمون ذلك. والبُعد عن التكلف وإرسال النفس على سجيتها. والتوزيع المحكم للمحركات الصرفية واللغوية في صياغة تعابيره بضروب من النغم الموسيقي. ولا بـدّ مـن الإشـارة إلى أن الباحث في الدراسـات الحديثيـة لا يجـد شيئاً من التحليل

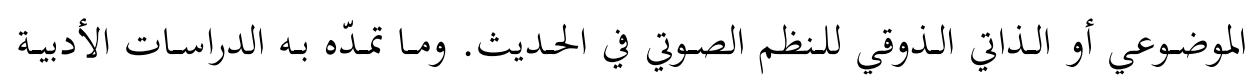

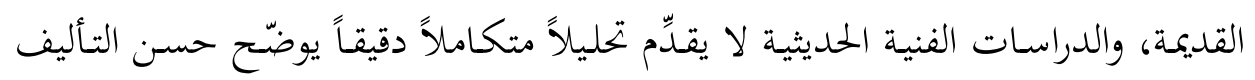

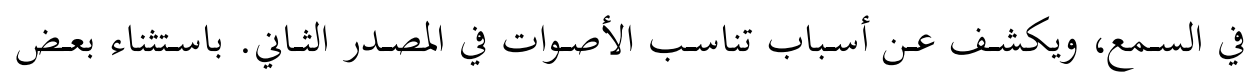
الإشارات الواردة في كتابات الرافعي في "إعجاز القرآن والبلاغة النبوية"، وأبحاث محمد

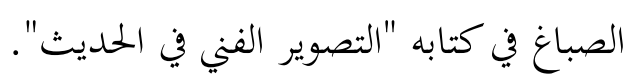

\section{Y. تجنب أسباب التنافر الصوتي في النظم الحديثي:}

إن لغة الحديث لغة موسيقية، تستريح الأذن إلى ألفاظها ونظمها المرتل، فهي تصنع

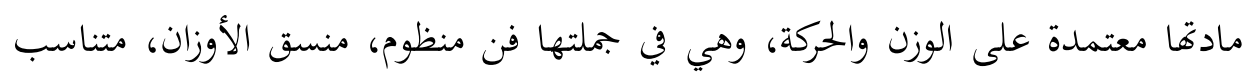

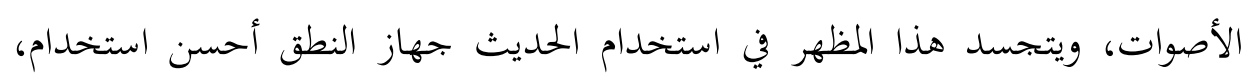
يهدي إليه الافتتان في الإيقاع الموسيقي.

لقد راعى الحديث في نسجه لعباراته تناسب الأصوات وحسن ائتلافها، وذلك ب:

\section{أ. تجنب تتابع الأصوات المتماثلة والمتقاربة:}

- بحنب الحديث الجمع بين ظاءين في مقطعين أو جملتين متتابعتين: 


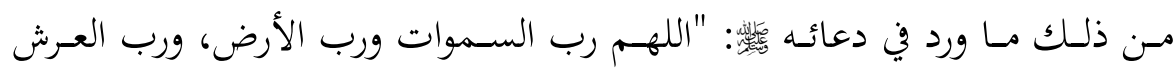
العظيم ربنا ورب كل شيء. فالق الحب والنوى، منزل التوراة والإنجيل، أنت الأول فليس ؤه

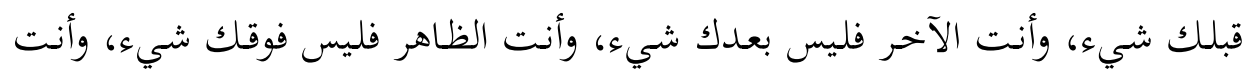

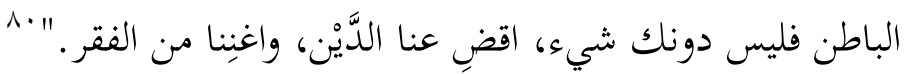
ذكر الحـديث حـرف "الظـاء" في المقطع الأول، وعـرض بعض صـفات البـاري في

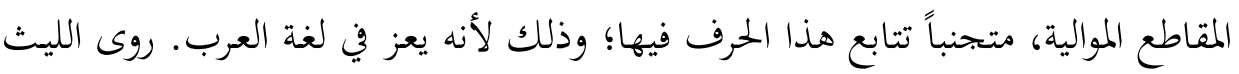
أن الخليل قال: "الظاء حرف عربي خصّ به لسان العرب، لا يشركهم فيه أحد من سائر

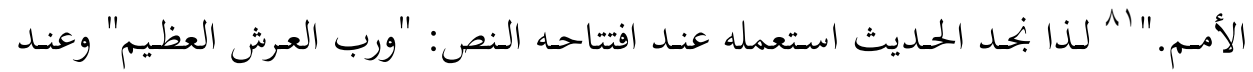
اختتامه: "وأنت الظاهر" وذلك مراعاة منه لحسن التأليف وجودة الصياغة.

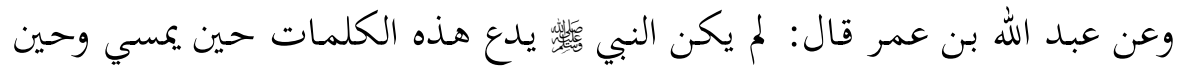

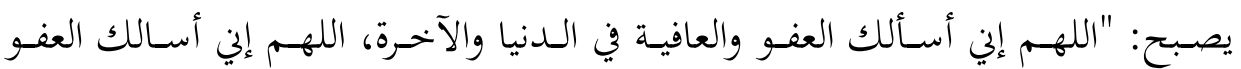
والعافية في ديني ودنياي، وأهلي ومالي، اللهم استر عوراتي، وآمن روعاتي، اللهم احفظني

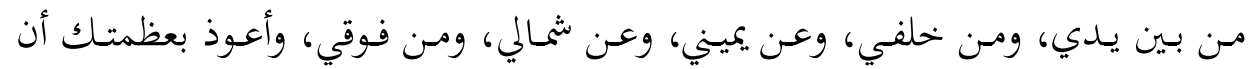
اغتال من تحتي.

ورد ذكـــ الظـاء وسـط الحسـديث وآخـره، ولم يـأت ذكرهـا في جملتـين أو مقطعـين

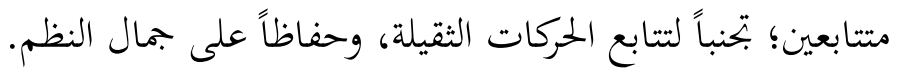
- بحنب الحلديث تكرار الحرفين المتماثلين: عن طلحة بن عبيد الله قال: جاء رجل إلى رسول الله يسمع دوي صوته، ولا يفقه ما يقول حتى دنا، فإذا هو يسأل عن الإسلام، فقال رسول الله لَّ •^ مسلم، الجامع الصحيح. مرجع سابق، كتاب: الذكر والدعاء، باب: ما يقول عند النوم وأخذ المضجع، حديث

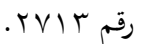

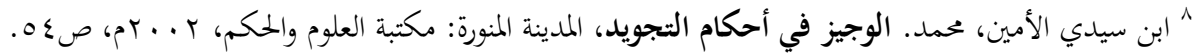

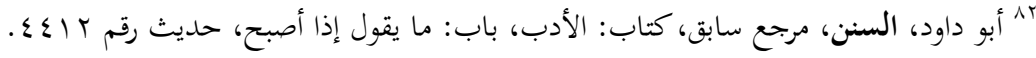




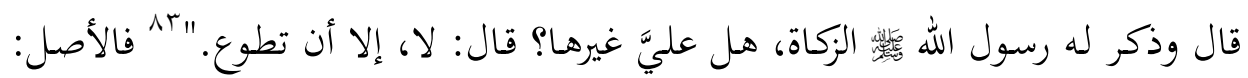

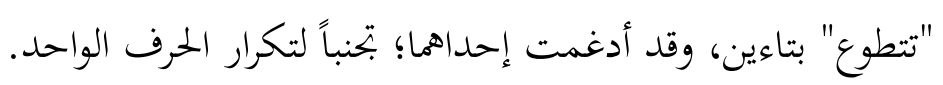

ورد في المثل السائر مـا نصه: "إن العرب الذين هـم الأصل في هذه اللغة قد عدلوا

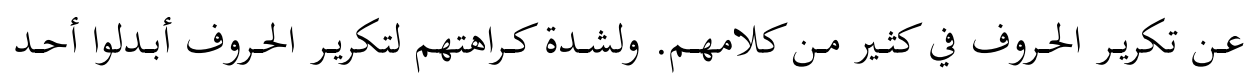

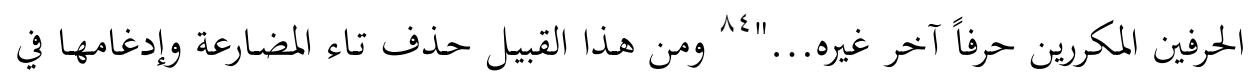

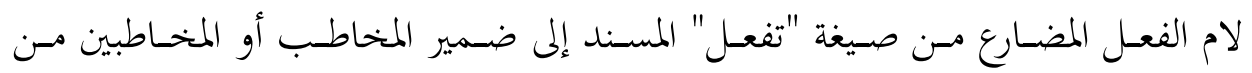

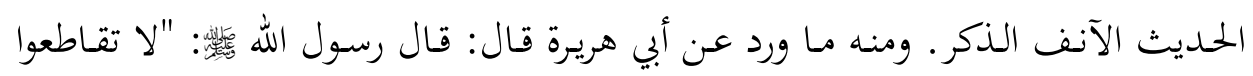

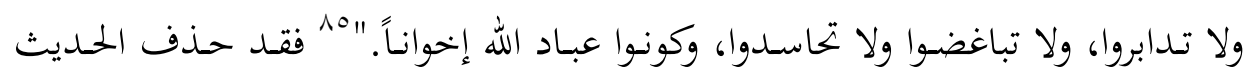

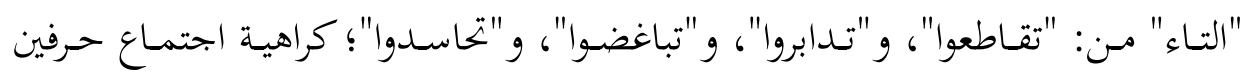
متماثلين، وهو كثير في الأسلوب الحديثي.

- بتجب تتابع الأصوات القوية:

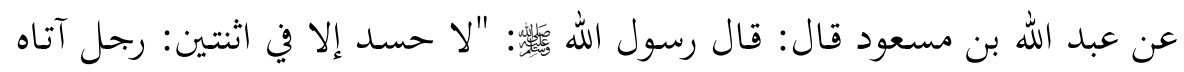

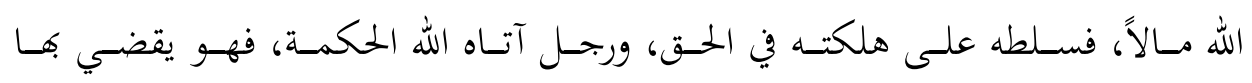

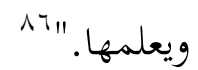

إن الحسد المذكور في النص هو الغبطة، ودلّ عليه مـا زاده أبو هريرة تِّئه في الحديث:

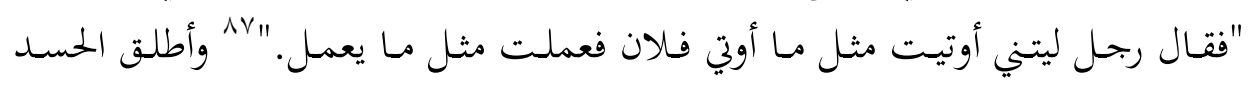

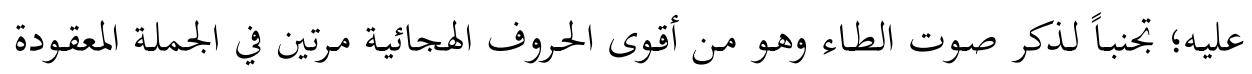

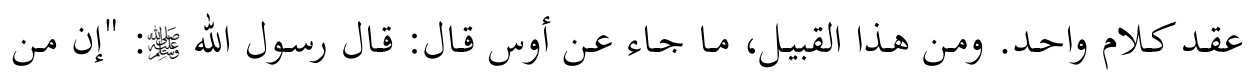

r^^مسلم، الجـامع الصحيح، مرجع سابق، كتاب: الإيمان، باب: بيان الصلوات التي هي أحسد أركان الإسلام،

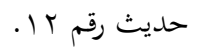

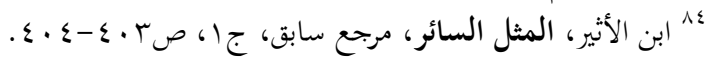

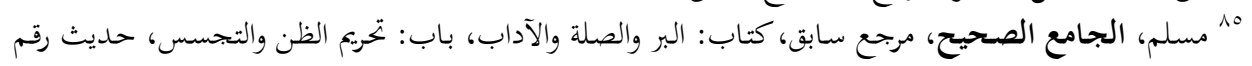

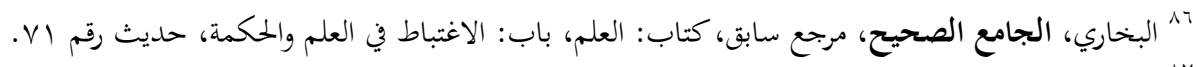

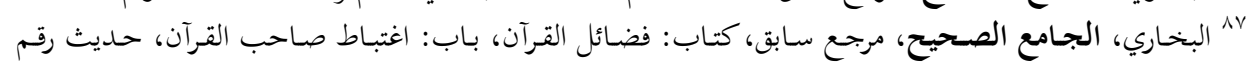




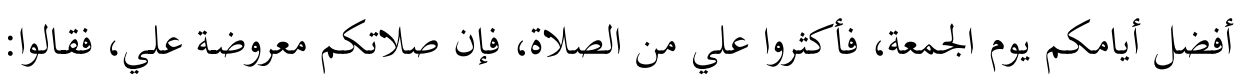

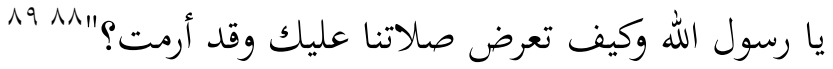

أصله "أرمتت"؛ أي بليت، فحذفت إحدى الميمين؛ تحنباً لتكرار الحرفين المتماثلين.

\section{ب. تجنب بعض الألفاظ والأبنية الصرفية:}

عدل الحديث عن استعمال بعض الألفاظ إلاّ بصيغة الجمعع، وعدل عن استعمال

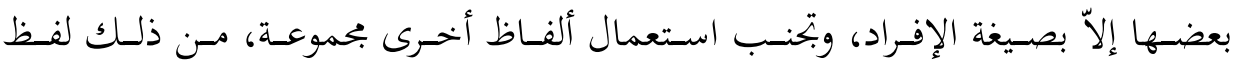

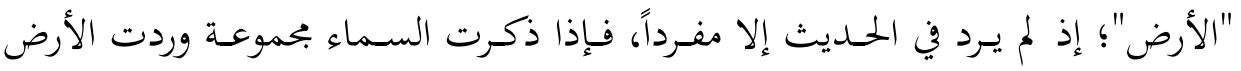
مفردة.

عن أبي هريرة هبئه: قال: قال أبو بكر: يا رسول الله مـري بشيء أقوله إذا أصبحت

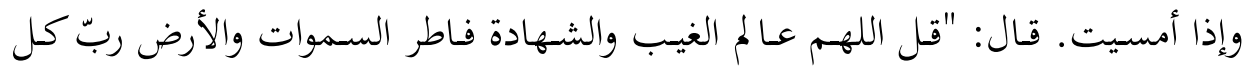

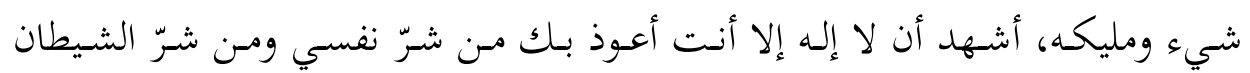

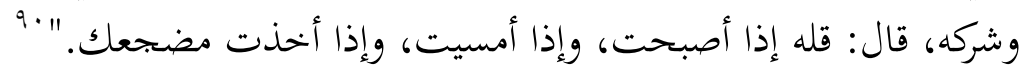

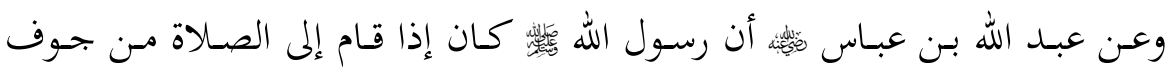

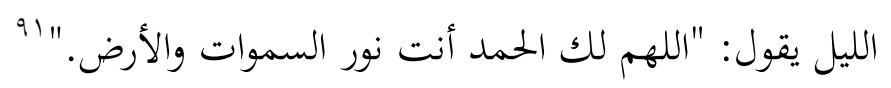

وبتحنب الحمديث النبوي استعمال بعض الألفاظ؛ طلباً لخفة العبارة، ومن ذلك لفظ "آمن" الذي هو أخف من صدق. لذا كثر ذكره في الحلديث الشريف، من ذلك ما جاء

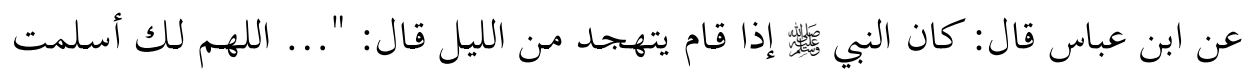

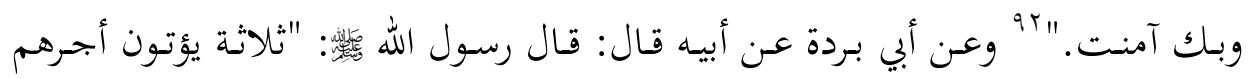

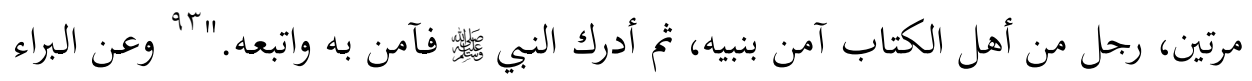

$$
\text { ^ ^ وأرمت؛ أي صرت رميماً. }
$$

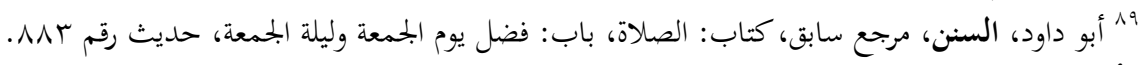

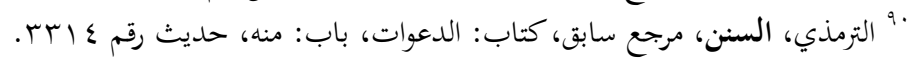

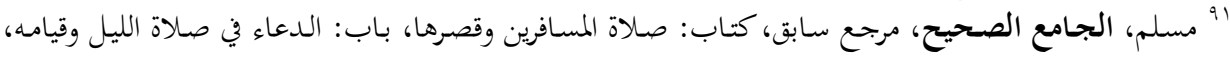

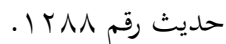

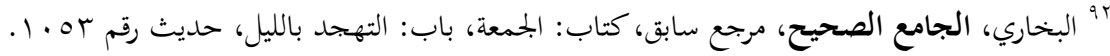

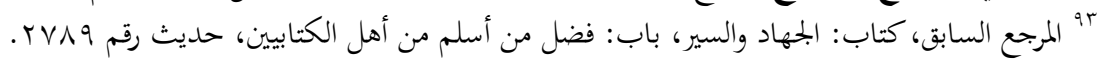




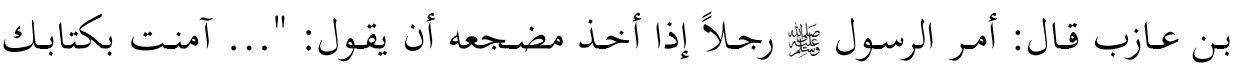

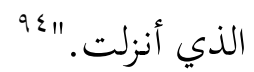

كما بتحنب الحديث النبوي صيغتي المضارع والأمر من فعل "جاء"، وعدل إلى مرادفه في نصوص كثيرة، دل استقراؤها على اطراد هذه القاعدة. فعن أبي موسى عن النبي فئس

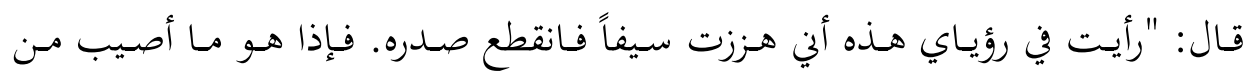

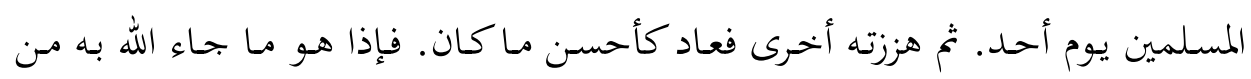

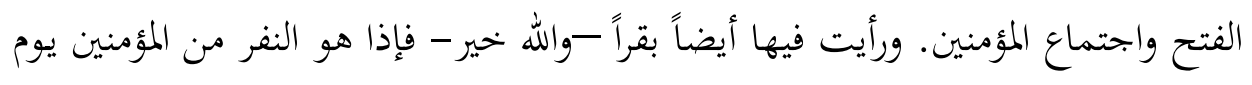

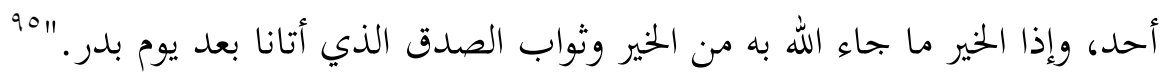

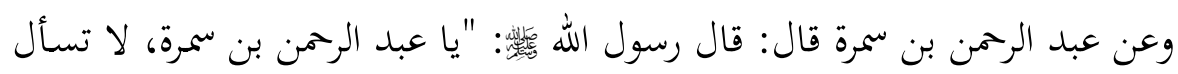

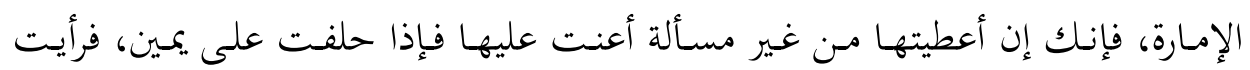

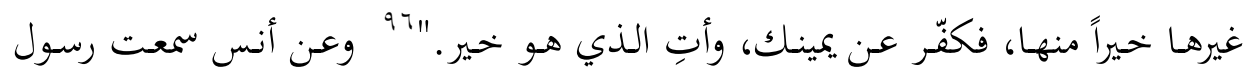
الله

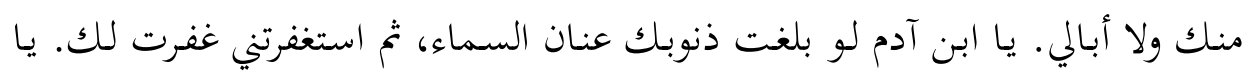

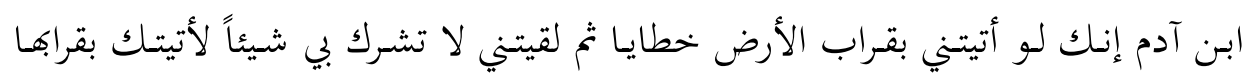

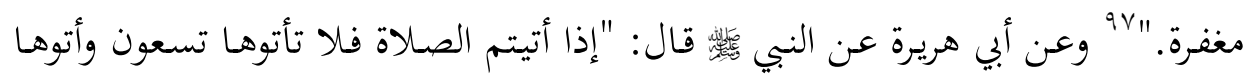

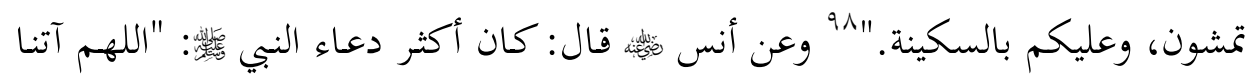

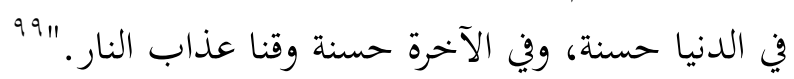

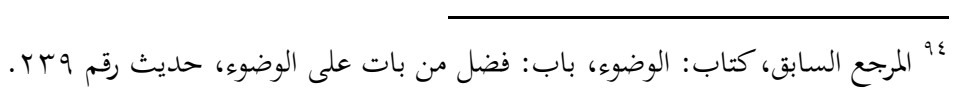

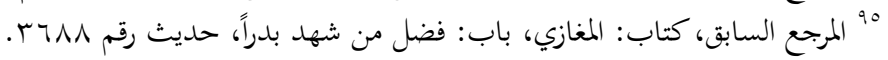

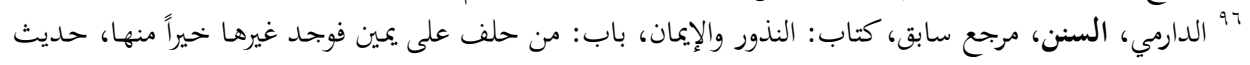

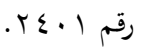
لو الترمذي، السنن، مرجع سابق، كتاب: الدعوات، باب: في فضل التوبة والاستغفار وما ذكر من رمة الله لعباده،

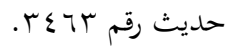

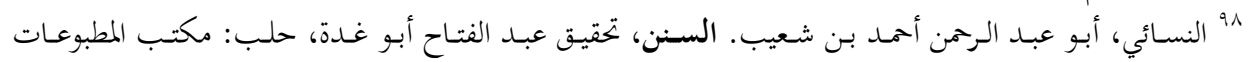

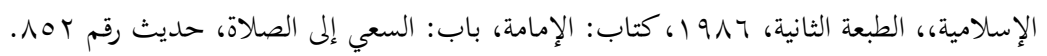

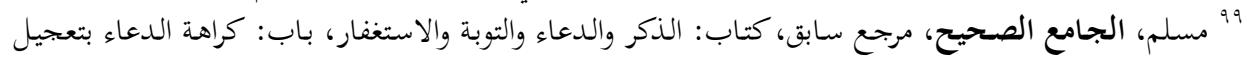

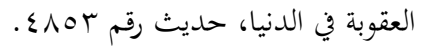




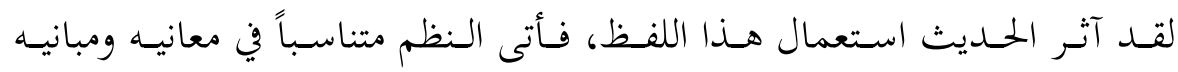

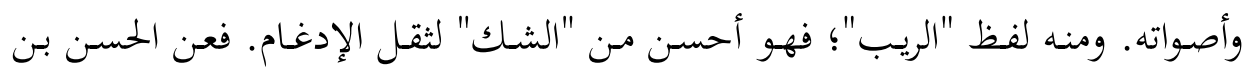

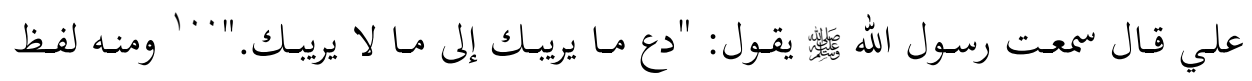

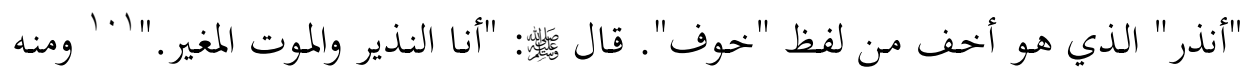

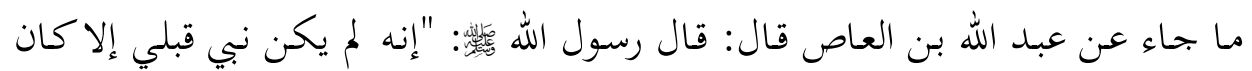

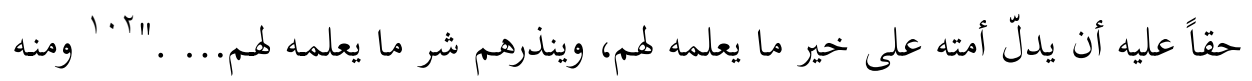

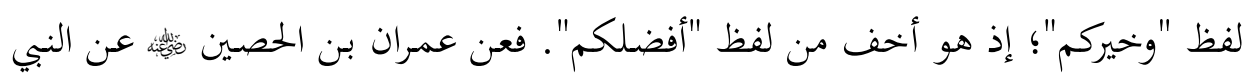

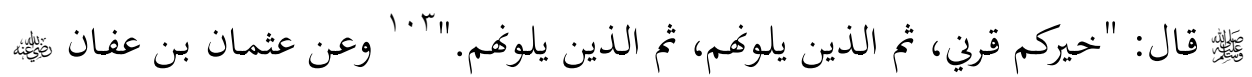

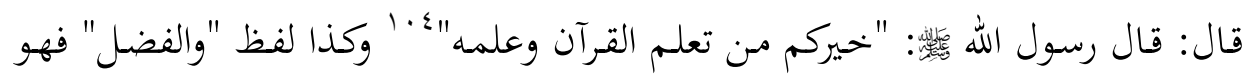

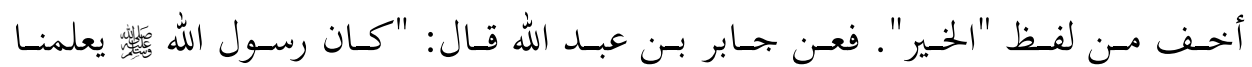

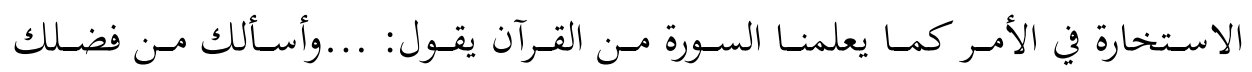

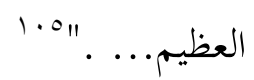

كما أن لفظ "نكح" أخف من لفظ "تزوج"؛ لأن "فعل" أخف من "تفعل"، ولذذا

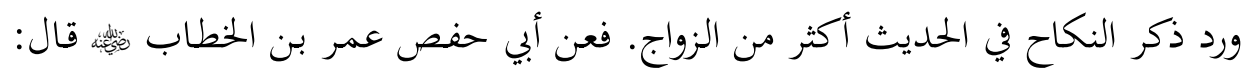

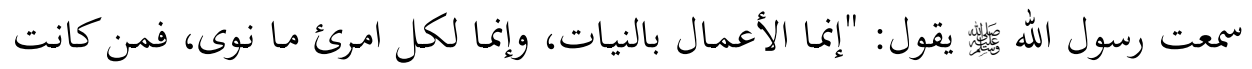
هجرته إلى الله ورسوله فهجرته إلى الله ورسوله، ومن كانت هجرته لدنيا يصيبها، أو امرأة

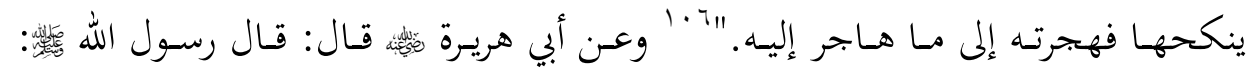

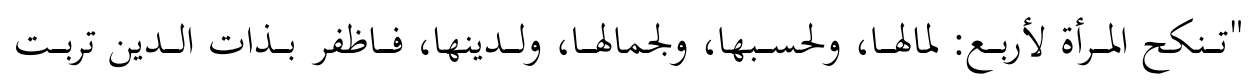
يداك."

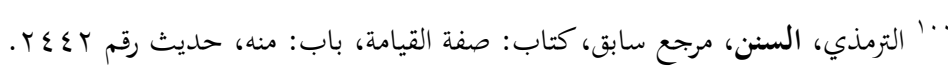

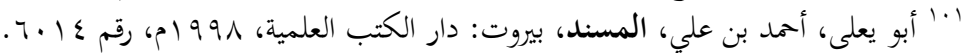

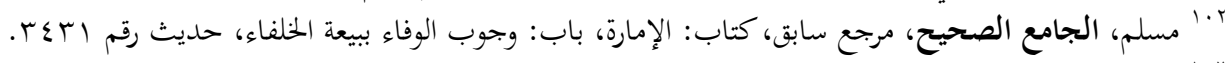

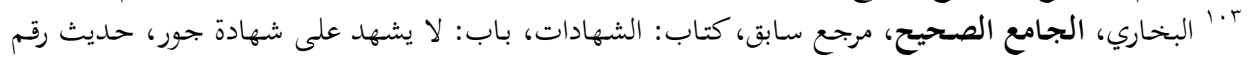

$. r \leqslant \circ V$

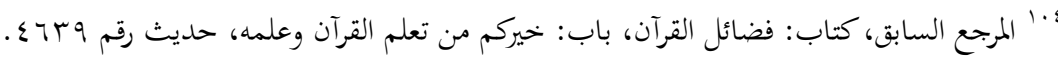

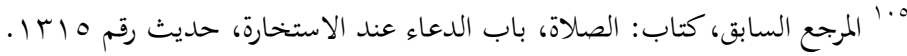

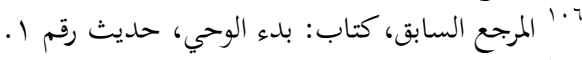

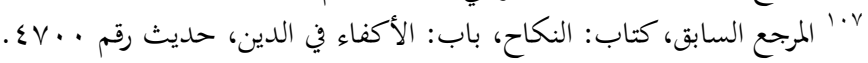




\section{ج. التناسب بين الدعنى والإيقاع الصوتي:}

لاحظت غالباً أن حروف العربية تناسب معانيها، وأن للحرف العربي قيمة تعبيرية في

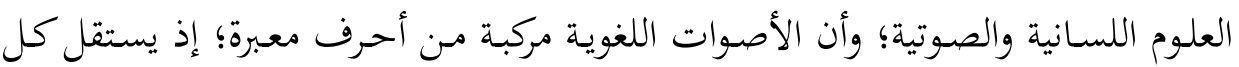

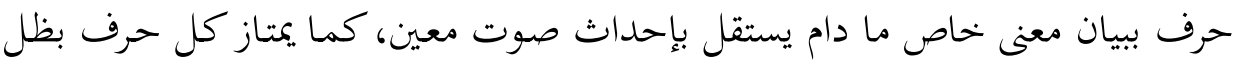

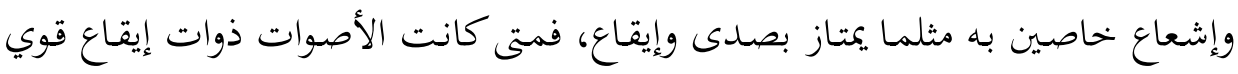

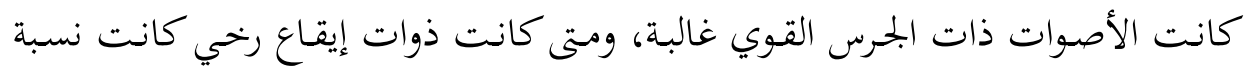
الأصوات اللينة والضعيفة هي الغالبة.

يراعي الـظم الحـديثي في توزيـع الأصـوات وتأليفهـا مـا يناسـب المعـاني والمقامـات،

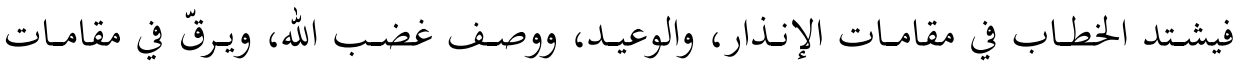
الترغيب والتلطف، ومخاطبة المؤمنين، وفي الأذكار، والأدعية. ولهذا كان لتوزيع الأصوات في الخطاب الحمديثي قيمة جلية في تكييف الإيقاع؛ شدة وليناً، قوة وضعفاً. وما يفيدنا

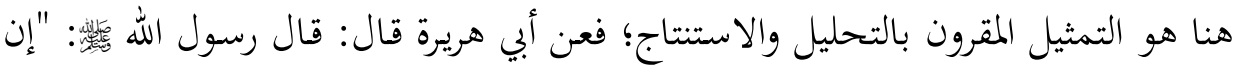

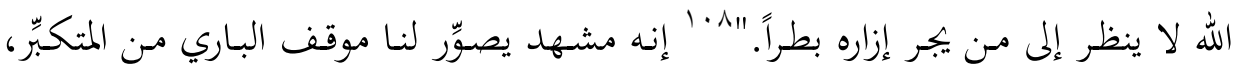

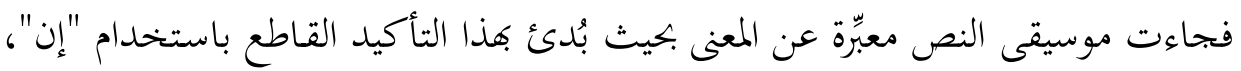
واستعمل الفعل المسبوق "بلا" النافية لزيادة بيان انصراف الله عمّن يقترف هذا المخظور.

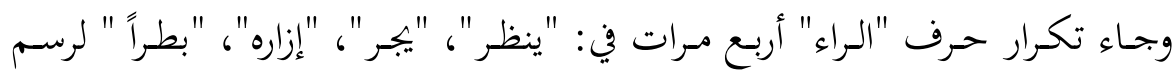
صورة معبّرة عن غضب الله على مَن ينازعه صفة من صفاته الذاتية.

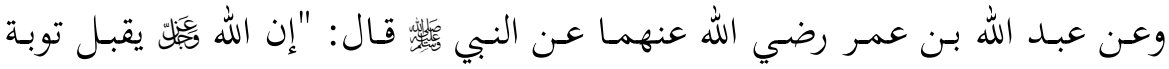

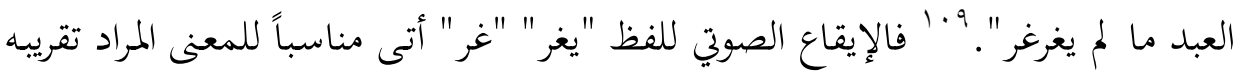
من المخاطب، وتكرار المقطع "يغرغر" جعلنا نحس الموقف الصعب والحركة الشاقة العسيرة

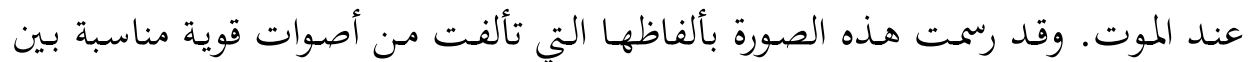

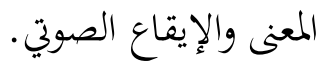

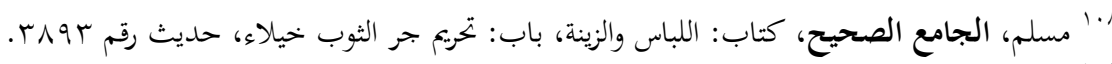

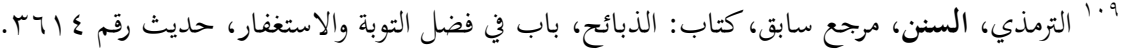




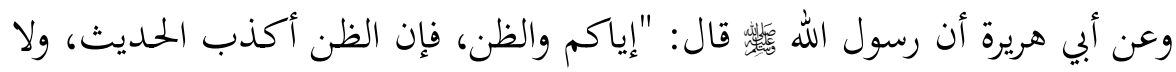

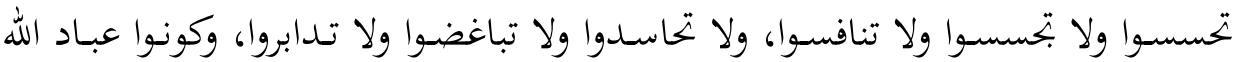
إخوانا، كما آمركم المسلم أخو المسلم لا يظلمه، ولا يخذله، ولا يحقره، التقوى ههنا ويشير إلى صدره- بحسب امرئ من الشر أن يحقّر أخحاه المسلم، كل المسلم على المسلم

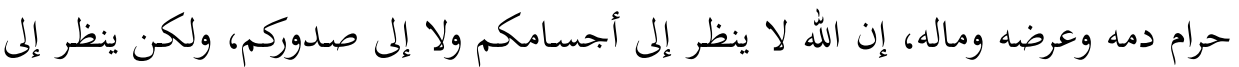

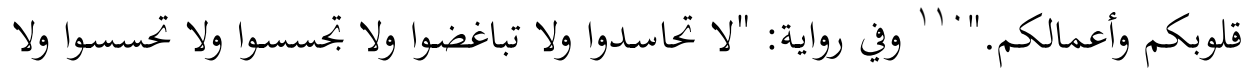
تناجشوا وكونوا عباد الله إخوانا."

مثَّلـت الموسيقى أبرز عناصـر الشكل في هـا النص، فأتـت متغيرة الإيقـاع بحسبب

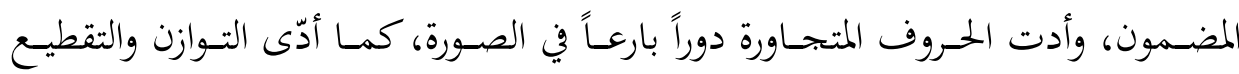

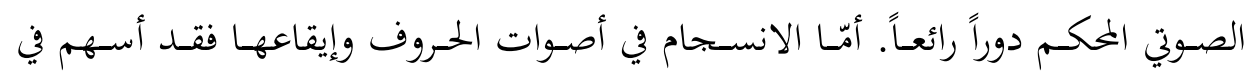

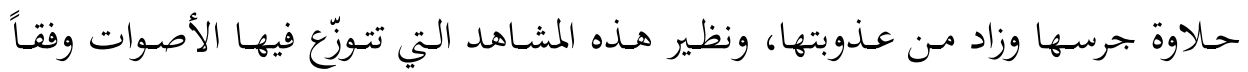

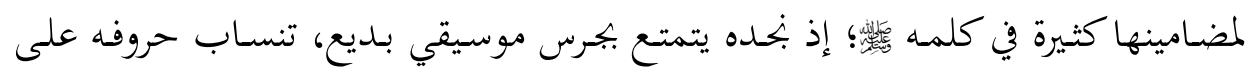

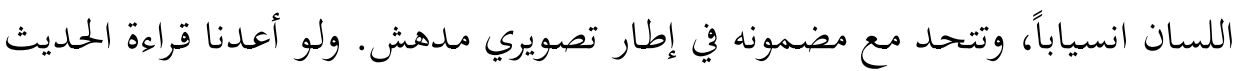

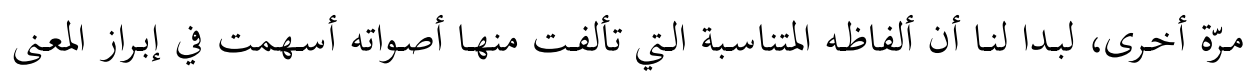

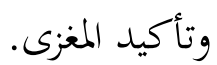

فالصـوت الـذي تكرّر في "الـدال" الممـدودة والمضـمومة في "تحاسـدوا"، و "تـدابروا"،

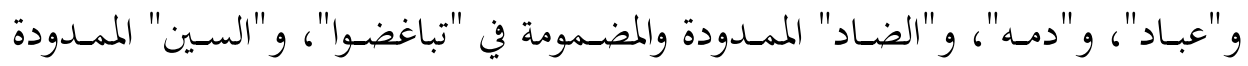

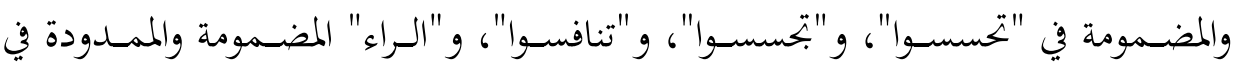
"تدابروا" عُبِّر فيه عن النهي بقوة وشدة.

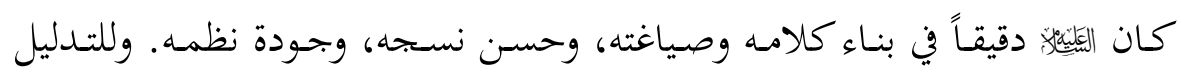
على هذا يمكن الرجوع إلى البمازات النبوية، فهي بتمع بين الوفاء بحق المعنى والتناسب

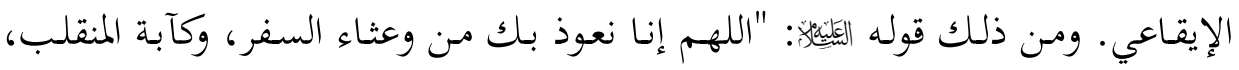
•” المرجع السابق، كتاب: البر والصلة والآداب، باب: تحريم الظن والتجسس والتنافس والتناجش وغخها، حديث رقم 


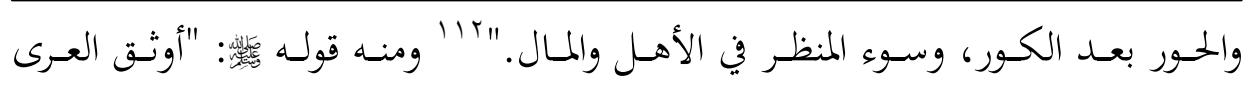

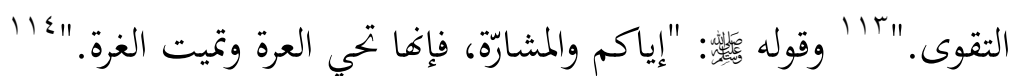

هكذا كان الئليَّة يعدل عن التعبير الحقيقي إلى الكناية أو البحاز؛ وفاءً بحق النظم، وأداءً للمعنى المراد إبلاغه.

ويرى ابن جني أن العدول إلى المحاز يكون لمعالٍ ثلاثة، هي: الاتساع، والتوكيد،

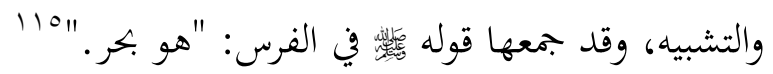

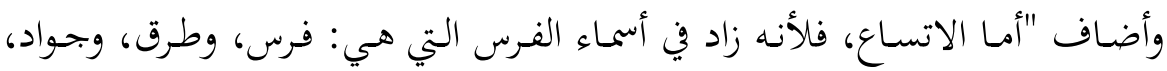

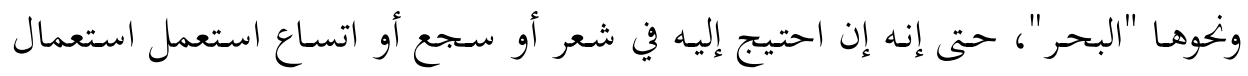

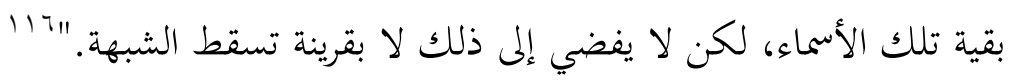

ونخلص إلى أنه كان يتجنب تناسب الفواصل، وإن أتاه، جمع فيه بين حق اللفظ إنظ

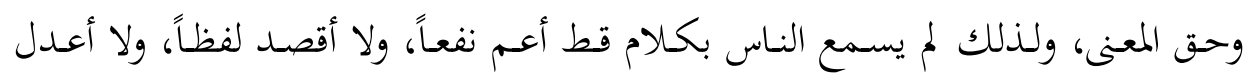

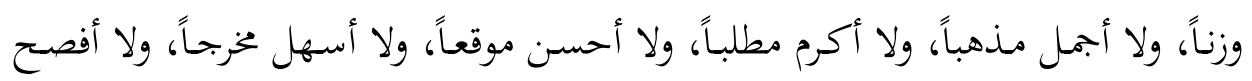

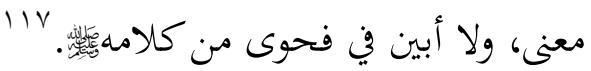

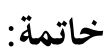

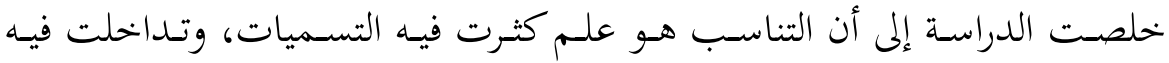

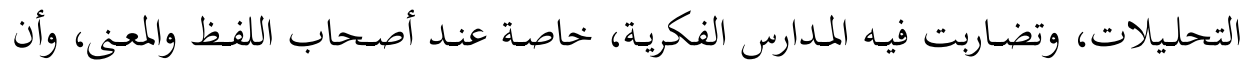

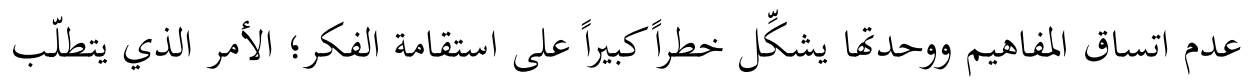

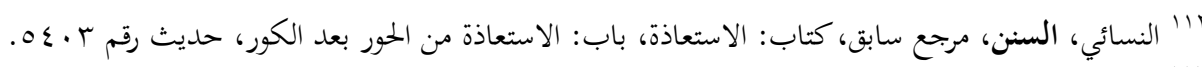

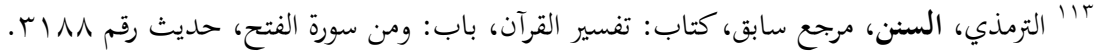

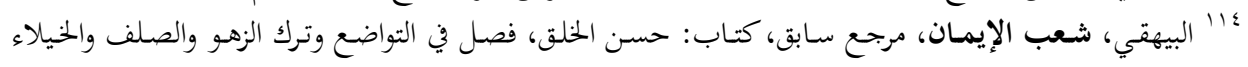

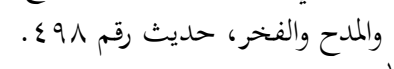

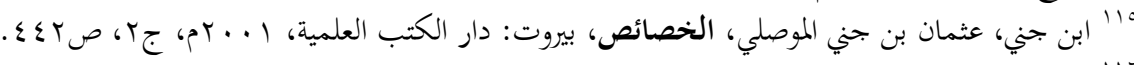

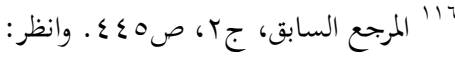

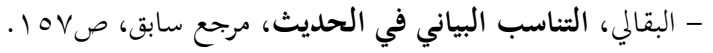

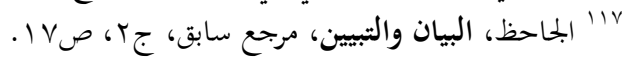


إيجـاد قاعـدة راسـخة لاستعمال مفهوم التناسـب. كمـا بيّنـت الدراسـة أن البـاحثين مـن

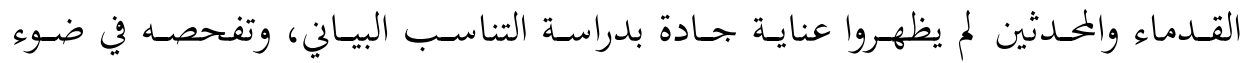

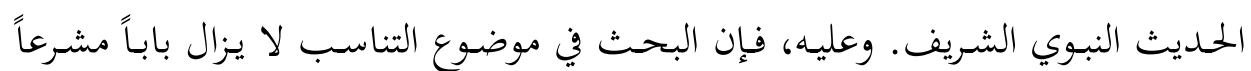

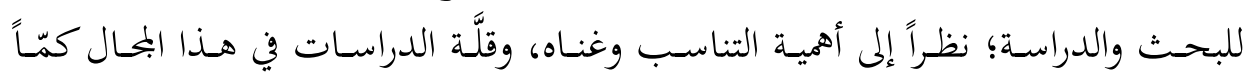
ونوعاً.

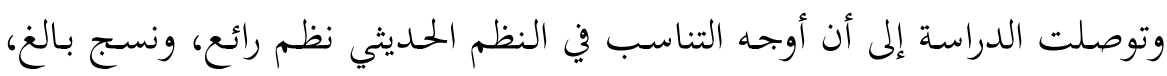

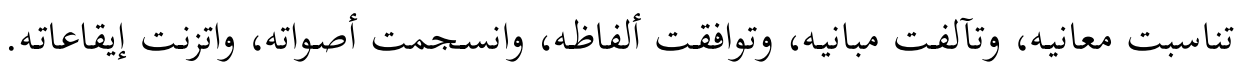

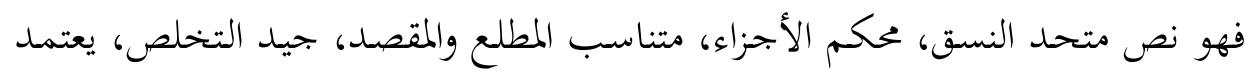

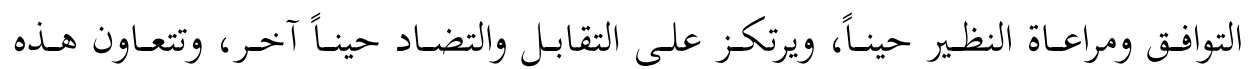

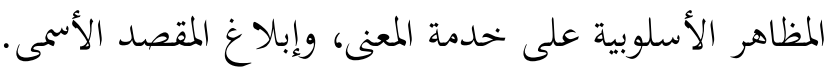

واتضـح مـن مبحـث التناسـب الصـوتي والإيقـاعي في الحـديث أن جـودة نظمـهـ مـن

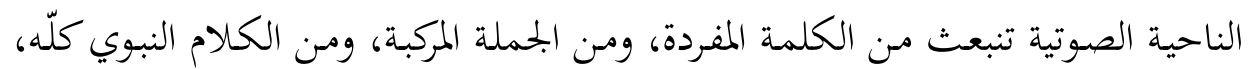

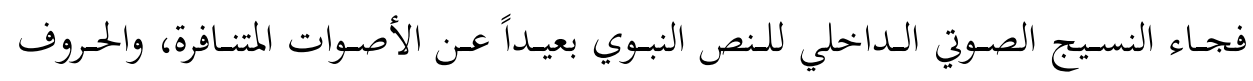

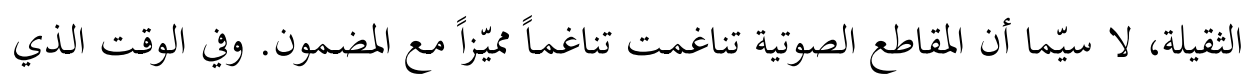
انتظمت فيه الحروف المتجاورة في الجملة بشكل بارع، أدّى التوازن والتقطيع الصوتي دوراً

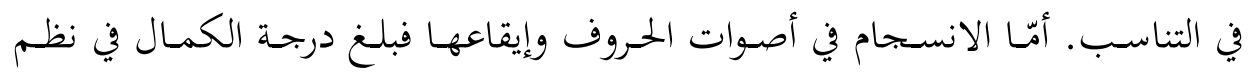
الحمديث. 